\title{
Salvador Dali, Sürrealizm ve Mobilya
}

\author{
Deniz DEMIRARSLAN ${ }^{1 *}$, Oğuz DEMIRARSLAN²
}

Öz

Katalan asıllı Sürrealist ressam Salvador Dali yaşamı boyunca 1500'ü aşkın eser vermiştir. Resim, heykel, illüstrasyon, dekor tasarımı, kostüm tasarımı, yazarlık gibi pek çok alanda çalışmaları olan sanatçı, sıra dışı kimliğiyle sanat dünyasında 20. Yüzyılın dâhisi olarak kabul görmüştür. Mobilya konusunda da çalışmaları olan sanatçı mobilyayı diğer sanat eserlerinde de bir metafor olarak kullanmıştır. Salvador Dali ile ilgili çok sayıda araştırma ve akademik kaynak bulunmakla birlikte sanatçının mobilya tasarımı konusundaki çalışmaları hakkında kaynaklar yetersizdir. Bu çalışmada, öncelikle Dali'nin sanat yaşamı ve eserlerine genel bir göz atılmış, Sürrealizm hakkında bilgi verilmiş, sürrealist sanatta mobilyanın anlamına değinilmiş, Dali'nin eserlerinde metafor olarak mobilya incelenmiş ve sanat yaşamında mobilyanın yeri ve önemi yapmış olduğu tasarımlar ve sanat yapıtları üzerinden incelenmiştir. Dali'nin çılgın, yoğun ve geniş kapsamlı sanat yaşamının mobilya kesiti üzerinden incelenmesinin amaçlandığı bu çalışmada sanatçının mobilya tasarımına katkıları belirlenmiştir.

Anahtar Kelimeler: Sürrealist mobilya, Tasarım, Bütüncül tasarım, Esinlenme, Metafor

\section{Salvador Dali, Surrealism and Furniture}

\begin{abstract}
The Catalan Surrealist painter Salvador Dali has produced more than 1500 works during his lifetime. With his extraordinary identity, the artist has been recognized as the genius of the twentieth century in the art world, having worked in a variety of fields including painting, sculpture, illustration, decor design, costume design, and writing. Furniture was used as a metaphor in other works of art by the artist, who also experimented with it. Although there are numerous academic and research publications on Salvador Dali, there are few resources on the artist's furniture design work. In this study, first and foremost, a general overview of Dali's art life and works was provided, as well as information about Surrealism, the meaning of furniture in surrealist art was mentioned, furniture was examined as a metaphor in Dali's works, and the designs and artworks that Dali created the place and importance of furniture in his art life. The artist's contributions to furniture design were determined in this study, which aimed to examine Dali's crazy, intense, and wide-ranging art life through the furniture section.
\end{abstract}

Keywords: Surrealist Furniture, Design, Holistic design, Inspiration, Metaphor

\footnotetext{
${ }^{1}$ Kocaeli Üniversitesi, Mimarlık ve Tasarım Fakültesi, İç Mimarlık Bölümü, Kocaeli, Türkiye

${ }^{2}$ Maltepe Üniversitesi, Mimarlık ve Tasarım Fakültesi, İstanbul, Türkiye

*ilgili yazar/Corresponding author: denizdemirarslan@gmail.com Gönderim Tarihi / Received Date: 08.06.2021

Kabul Tarihi / Accepted Date: 27.08.2021
} 


\section{Giriş}

"Dâhi değilsen bile öyle davran, kesin dâhi sanırlar."

Eserlerini oluştururken düşler, korkular ve hayallerden esinlenen, 20. Yüzyılın en önemli sürrealist sanatçılarından biri olan Katalan asıllı Salvador Dali (1904-1989) resimler, taş baskılar, heykeller, illüstrasyonlar, enstalasyon sanatı, mücevher, mobilya, film, senaryo, tiyatro dekorları ve kostümler gibi eserlerden oluşan 1500'ü aşkın sanat eserine imza atmıştır. Dali, öncelikle sürrealist resimleriyle ünlenmiştir. En ünlü sürrealist eseri "Belleğin Azmi (The Persistence of Memory/ (Soft Watches)" (1931) isimli çalışmasıdır. Sürrealist sanatın en önemli çalışması olarak kabul edilen bu resimde Dali, Katalonya'nın "Cape Creus" sahilinde erimiş "Camembert" peynirini simgeleyen erimiş saatleri konu almaktadır. Bu resminde Freud'un rüya ve bilinçaltı konusundaki görüşlerinden etkilendiği, zaman kavramını yeniden yorumladığı belirtilmektedir. Resimde zaman mekândan bağımsız olarak ele alınmaktadır (Resim1). McNeese eserinde (2006, s.69), bu resmi kalabalık ve kinetik aynı zamanda odaklanması zor bir o kadar da kompozisyon açısından dengeli olarak tanımlamaktadır. Yapıt, "dikkatle seçilmiş bilinçdışı" bir şaheser olarak tanımlanmaktadır. Resimde görülen kayalıklar zamana karşı direnen katı formları simgelerken, saatler akıp giden zamanı, saatlerin temsil ettiği peynir ise çocukluğunu ve babasını temsil etmektedir.
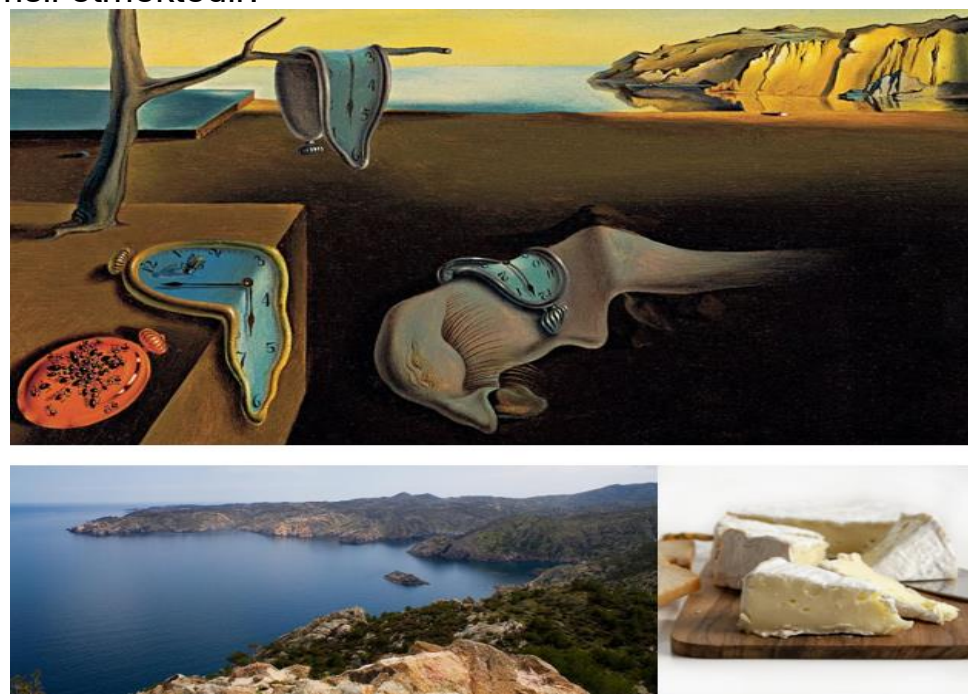

Resim 1."Belleğin Azmi”, "Cape Creus" Sahili ve "Camembert Peyniri (URL-1).

Ancak sanatçı yukarıda da değinildiği üzere; resimlerin yanı sıra farklı alanlarda da eserler üretmiştir. Sayıca az da olsa mobilyaya ilişkin çalışmaları bulunmaktadır. Bu mobilyaları genellikle resimlerindeki kompozisyonun bir parçası olarak düşünmüştür. Bu çalışmada Dali'nin gözünden mobilya incelenecektir. Çalışma kapsamında öncelikle sanatçının otobiyografisi ve sanatçı hakkında yazılmış kitaplar ile akademik yayınlar okunmuştur. Sanatçının Dünya müzelerinde yer alan eserleri ve sergileri incelenmiştir. Özellikle mezarının da içinde yer aldığı ve eserlerinin büyük çoğunluğunun bulunduğu Barcelona Salvador Dali Müzesi başta olmak üzere müzelerde yer alan eserleri incelendikten sonra uluslararası müzayede sitelerinde sanatçının eserleri araştırılarak mobilya tasarımlarına ve mobilyaya ilişkin çalışmalarına dair veriler toplanmıştır. Sanatçının mobilyalarını üreten firmalardan mobilyalarına ilişkin teknik bilgiler elde edilmiştir. "Belleğin Azmi" örneğinde olduğu gibi diğer çok sayıdaki resim çalışmasında da imgelerle bir anlatım dili oluşturan Dali'nin gözünden mobilya konusunu 
anlayabilmek için sanatçının sanat anlayışı ve Sürrealist sanat akımının özelliklerine değinmek gerekmektedir.

\title{
2.Salvador Dali'nin Sanat Hayatı
}

\author{
"Adım Salvador Dali, \\ Yani modern resmin kurtarıcısı anlamına geliyor; \\ Geleceğin resmine ulaşan ana yolu bulduğum inancındayım."
}

Salvador Dali

Salvador isimli ağabeyinin vefatı üzerine Dünyaya gelen Dali'ye, ailesinin sık sık ölen ağabeyinden bahsetmesi, yatağının başucunda ağabeyinin asılı fotoğrafına bakarak çocukluğunu geçirmesi, sanatçının erken yaşta kimlik karmaşası yaşamasına ve sürekli ismini taşıdığı ölen ağabeyi ile mukayese edilmesinin kendisinde bir takım değişik düşüncelerin gelişmesine neden olduğu söylenmektedir. Dali bu durum için otobiyografisinde şöyle açıklamada bulunmuştu:

"Iki su damlası gibi birbirimize benziyorduk, fakat yansımalarımız farklıydı. $O$, herhalde benim fazla mutlak olarak tasarlanmış ilk versiyonumdu." (Dali, 1948,s.2).

Resim çalışmaları konusunda annesinden destek görmüş; 1914'de bir sanat okulunda eğitime başlamış ve 1919'da ilk sergisini açmıştır (Caws, 2008, s.38). Dali 1948 yılında kaleme aldığı "The Secret Life of Salvador Dali/ Salvador Dali'nin Gizemli Yaşamı" isimli otobiyografisinde 1921 yılında annesinin vefatının kendisini çok sarstığını şöyle dile getirmişti: "Hayatımda yaşadığım en büyük darbeydi. Anneme tapardım...". Annesine olan düşkünlüğü ileriki yaşlarında eserlerine yansıyacaktı. 1922'de Madrid'de eğitim hayatına devam etmiş; Dadaizm ve Kübizm alanında eserler üretmiştir (Resim2). İspanya'da henüz yaygın olmayan bu akımlar Dali ile İspanya'ya tanıtılmıştır. Sürrealist film yapımcısı, yönetmen ve senarist Luis Buñuel ve şair, ressam, aynı zamanda oyun yazarı Federico García Lorca ile olan yakın dostluğu sanatının da etkilenmesine yol açmıştır (Edwards, 2009, s.88). 1926'da Pablo Picasso ile tanışması eserlerine Picasso etkisi olarak yansımıştır. Picasso bu durumu anılarında şöyle anlatmaktadır (Shanes, 2011, s.19):

“Picasso'nun Rue de la Boetie'deki stüdyosuna vardığımda derinden duygulandım ve sanki Papa'ya saygı duyuyormuşum gibi saygı duydum. Louvre'u ziyaret etmeden önce "Seni görmeye geldim" dedim. "Çok haklısın," diye yanıtladı. Özenle paketlenmiş küçük bir tablo getirdim O'na: "Figueres Kızı". Hiç yorum yapmadan tabloya uzun uzun baktı. Giderken "kaptın bu işi" dedi."

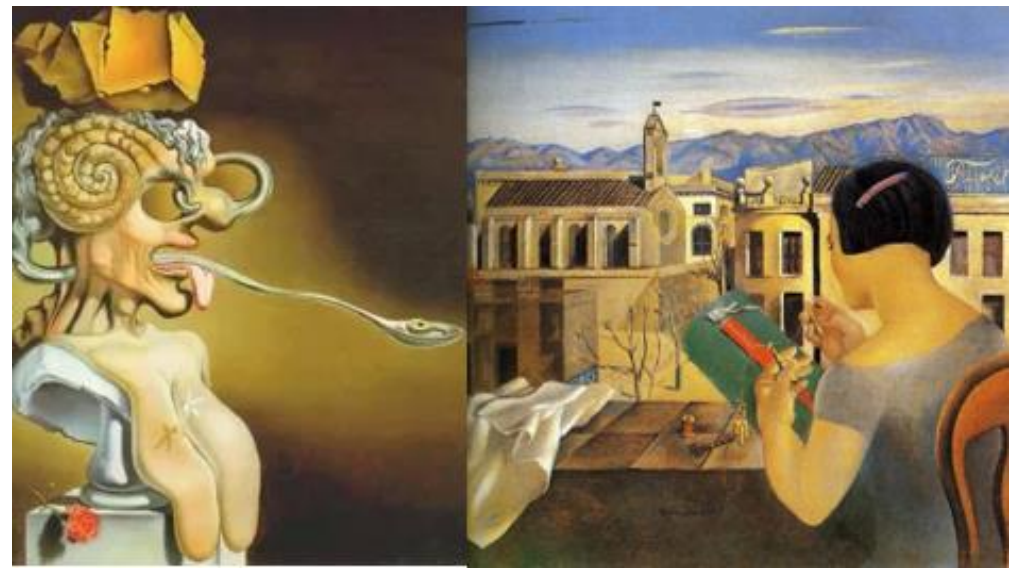

Resim 2. Salvador Dali'nin Gözünden Picasso (1947), Dalí Theatre-Museum, (Shanes, 2011, s.19), "Figueres Kızı/ The Girl of Figueres", (1926) (McNeese, 2006, s.15). 
1928 yılında sanat eleştirmenleri Luís Montanyà ve Sebastià Gasch ile birlikte, sanatta modernizmi ve fütürizmi savunan "Sanat Karşıtı Katalan Manifesto" ya da diğer bilinen adıyla "Sarı Manifesto"yu yazdı. Bu manifesto, Katalonya'daki ve muhtemelen İspanya'daki tarihi avangartların en önemli manifestosu haline geldi (Resim-3). Genç Katalanlara hitaben, kültürel ve şiddetle savunulan her şeyin çürümüş halini, Fütürist ve Kübist mirasını ve Dada'nın yönlerini kınadı. "Tavrımızdan tüm nezaketi ortadan kaldırdık. Bugünün Katalan kültürünün temsilcileriyle yapılacak herhangi bir tartışma, diğer düzenlerde sanatsal açıdan olumsuz olsa da verimli oldukları için anlamsız." Şeklinde bir ifade bu bildirgede yer almaktadır (Resim-3) (Lubar, 2006,s.339). Sayesinde sanatsal ve kültürel çevrelerde Sürrealist gruplarla tanıştığı "Bir Endülüs Köpeği" isimli avangart film ile sanat dünyasının ilgisini çeken sanatçı film senaryoları da yazmıştır. Çılgın giyim tarzıyla insanların dikkatini çekmiş; aynı zamanda Christian Dior, Elsa Schiaparelli ile moda tasarımı üzerine çalışmıştır (Resim-4). Man Ray, Brassaï, Cecil Beaton ve Philippe Halsman gibi zamanın ünlü fotoğraf sanatçılarıyla birlikte eserler üretmiştir. Çok yönlü tasarım kişiliğine sahip sanatçının yukarıda da belirtildiği üzere 1500'ü aşkın çok farklı alanlarda üretilmiş sanat eseri bulunmaktadır.

\subsection{SALVADOR DALÍ \\ Yellow Manifesto}

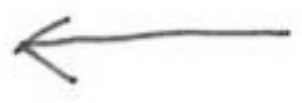

1928

We have eliminated from this MANIFESTO all courtesy in our attitude. It is useless to attempt any discussion with the representatives of present-day Catalan culture, which is artistically negative although efficient in other respects. Compromise and correctness lead to deliquescent and lamentable states of confusion of all values, to the most unbreatheable spiritual atmospheres, to the most pernicious of influences. An example: La Nova Revista. Violent hostility, in contrast, clearly locates values and positions and creates a hygienic state of mind.

\begin{tabular}{|c|c|c|}
\hline WE HAVE ELIMINATED & all reasoning & There exists an enor- \\
\hline WE HAVE ELIMINATED & all literature & mous bibliography and \\
\hline WE HAVE ELIMINATED & all poetry & all the effort of artists of \\
\hline WE HAVE ELIMINATED & $\begin{array}{l}\text { all philosophy } \\
\text { in favour of } \\
\text { our ideas }\end{array}$ & today to replace all this. \\
\hline
\end{tabular}

WI CONFINE OURSELVES WE CONFINE OURSELVES to the most objective listing of facts.

to pointing out the grotesque and extremely sad spectacle of the Catalan Intelligentstu of today, shut in a blocked (intelligensia) and jutrelied atmosphere.

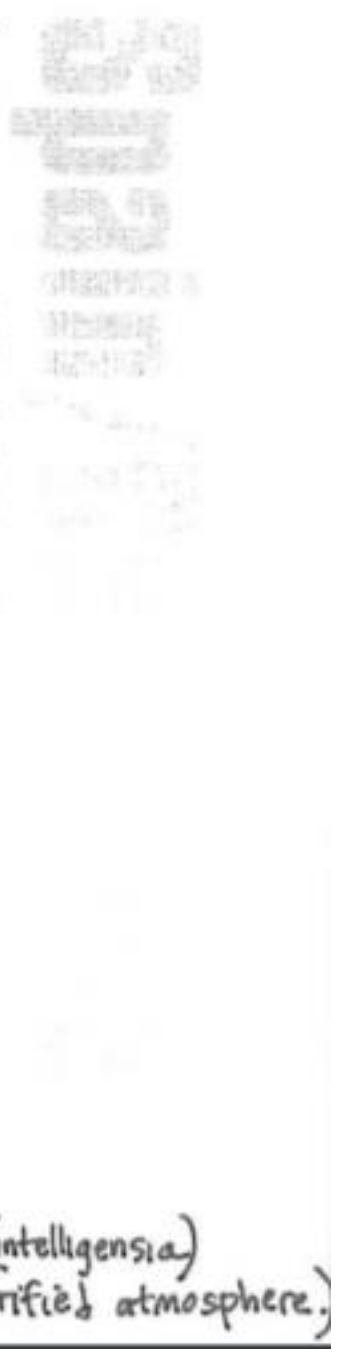

Resim 3. Sanat Karşıtı Katalan Manifesto (1928) (URL-2). 


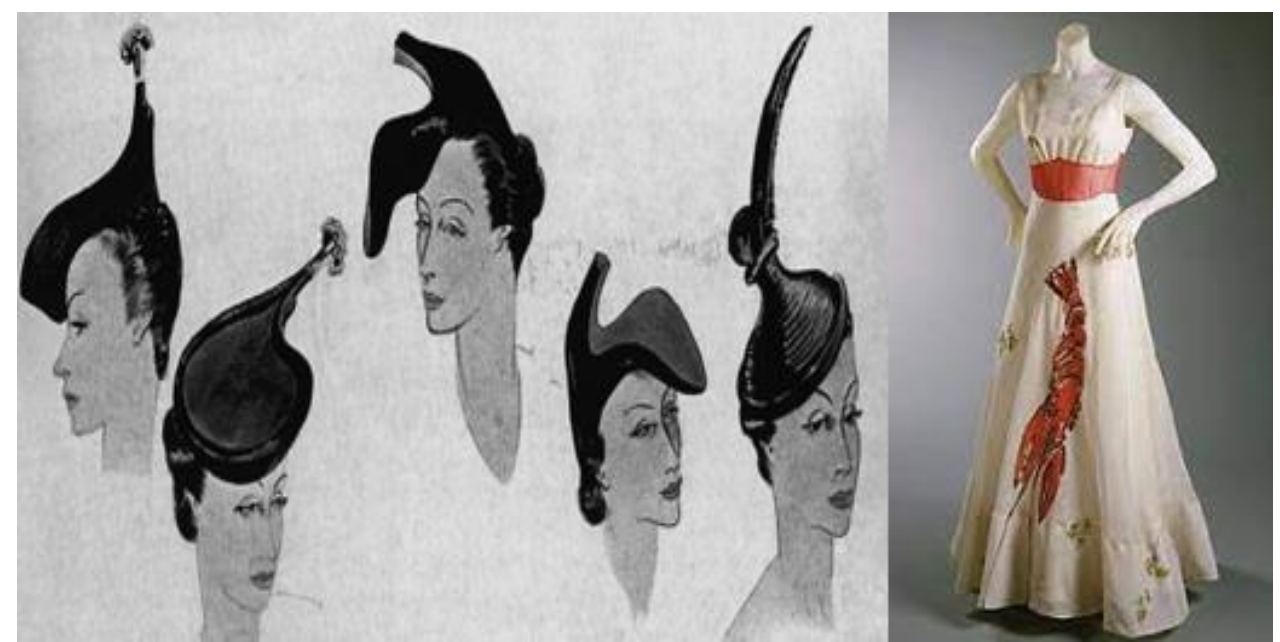

Resim 4. Elsa Schiaparelli İçin Tasarladığı Şapka ve Giysi,1936 (Anderson, 2002,s.28).

Enstalasyon sanatı üzerine eserleriyle insanları şaşırtan Dali'ye göre Dünyanın en büyük Sürrealist anıtı, bir enstalasyon sanatı örneği olan "Rainy Taxi/ Yağmurlu Taksi" isimli eseriydi (Resim-5). Çeşitli etkinlik ve sergilerde enstalasyonları ile sanatının şaşırtıcı yönünü insanlara göstermeye devam etmiştir.

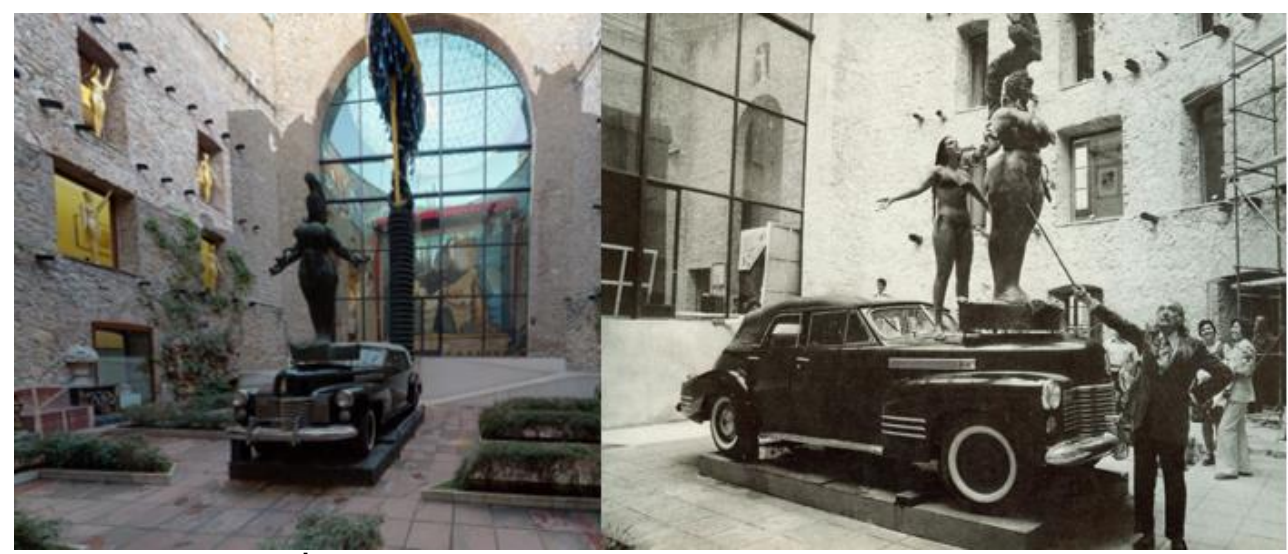

Resim 5. "Rainy Taxi” İsimli Enstalasyon Çalışması Bugün Dali Müzesi'nde Yer Almaktadır (URL-3).

Kadın imgesi bazı resimlerinin önemli konusuydu. "Jeolojik yankı. Pietà" (1982) eserinde Dali Rönesans'ın ünlü sanatçısı Michelangelo'nun eserini kaya formunu ve renklerini esas alarak yeniden yorumlamıştır. Eşinin rahatsızlandığı döneme denk gelen bu yapıt derin bir melankolik ruh haliyle yapılmıştır (Resim-6) (URL-3). Aile bireylerini konu ettiği resimlerinde ise portrelerin başında babasının portreleri gelmektedir. "Babamın Portresi/ "Retrato de mi padre" (1920-1921) isimli çalışması gençlik dönemine aittir. Bu, ilk bakışta, genç çocuğun babasına karşı kısa süreli sevgisini tasvir eden bir görüntüdür. Tabloda izlenimcilik etkisi hissedilmektedir (Resim6). Illk dönem resimlerinde izlenimcilik ve kübizmin etkisiyle manzara ve şehir resimleri de çalışmıştır. Bu eserlerindeki perspektif ve derinlik etkisi ilgi çekicidir. 1945 yılında yaptığı "Galarina" isimli tablosu eşinin gerçekçi bir portresidir: "Bu resme Galarina adını verdim çünkü Gala benim için Fornarina Raphael için neyse odur. " (Resim-6) (URL-4). Sanatçının Cadaques ve Port Algauer şehirlerini konu alan bir dizi resim çalışmaları da bulunmaktadır. Çocukluğunda yaz aylarını geçirdiği Port Alguer kasabasının konu olduğu tabloda yine Kübizm etkisi ön plandadır (Resim-7,8). Ressam çocukluk ve gençlik yıllarının geçtiği sahil kasabalarını resmetmiştir. Kendinden önceki ressamların 
ikonik eserlerini yeniden yorumladığı eserlerde Sürrealist etkiler görülmektedir. Dali'nin bu resimleri yaparken geçmiş hatıralara dönüşü etkili olmuştur. Örneğin; Jean-François Millet'in "The Angelus" isimli eseri sanatçıya okul yıllarında sınıfının penceresinden gördüğü taşra manzarasını hatırlatmaktaydı (Resim-9) (Shanes, 2011,s.127).

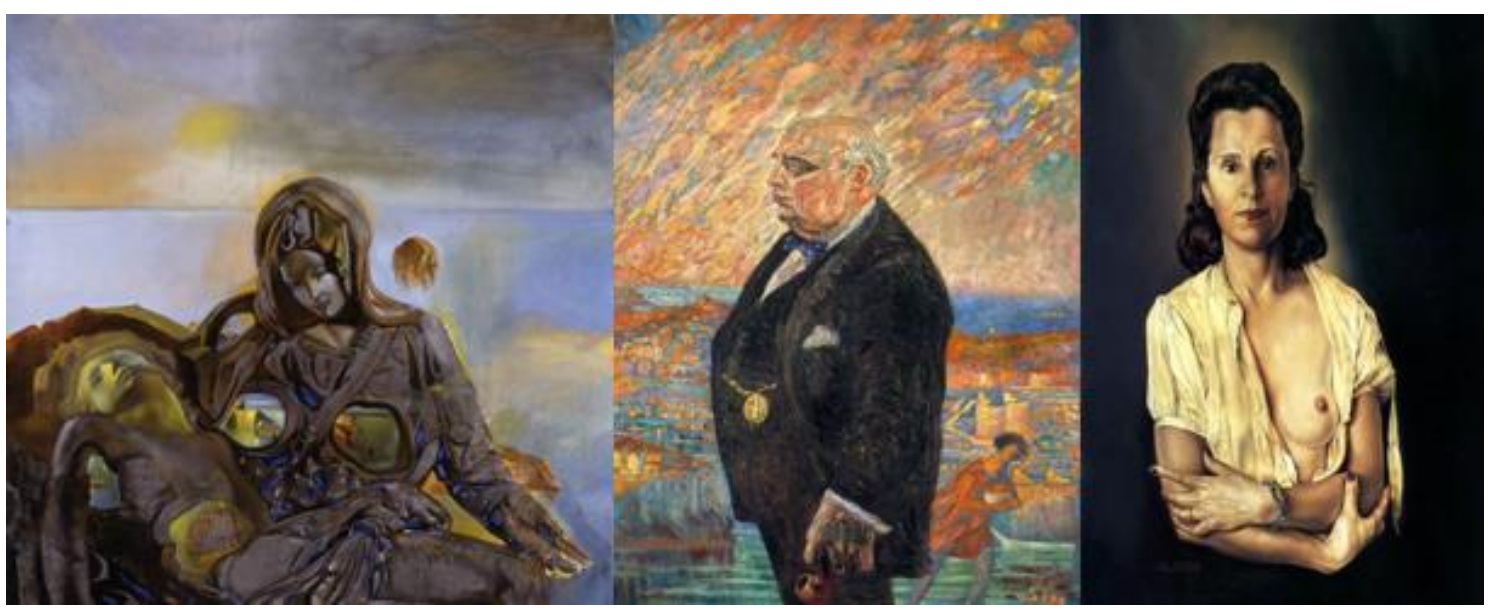

Resim 6. "Jeolojik Yankı, Pietà" (1982) (Demirarslan, 2008), "Babamın Portresi/ "Retrato de mi padre" (1920-1921), "Galarina" (1945) (URL-5) (İstanbul'da Bir Sürrealist Salvador Dali Sergi

Kitapçığı, 2008, s.25).
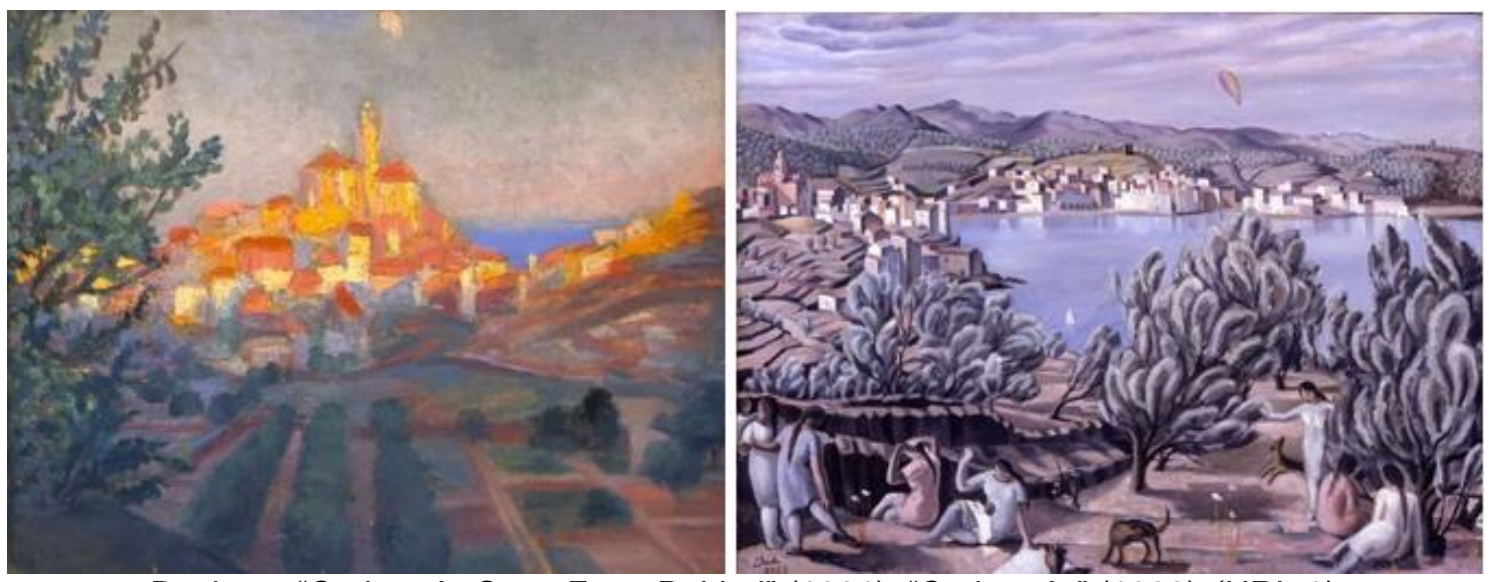

Resim 7. "Cadaqués Seen From Behind" (1921); "Cadaqués" (1923) (URL-6).

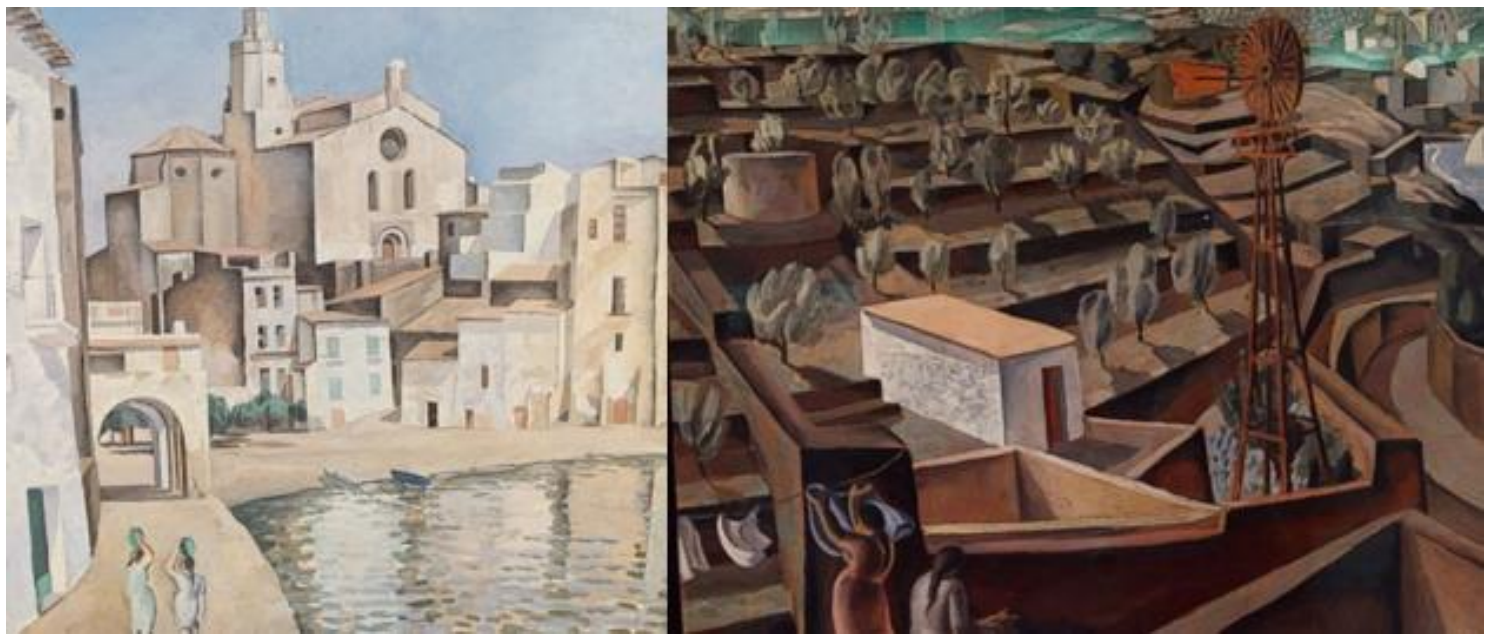

Resim 8. "Port Algauer” (1923); "El Moli-Cadaques" (1923) (URL-3). 


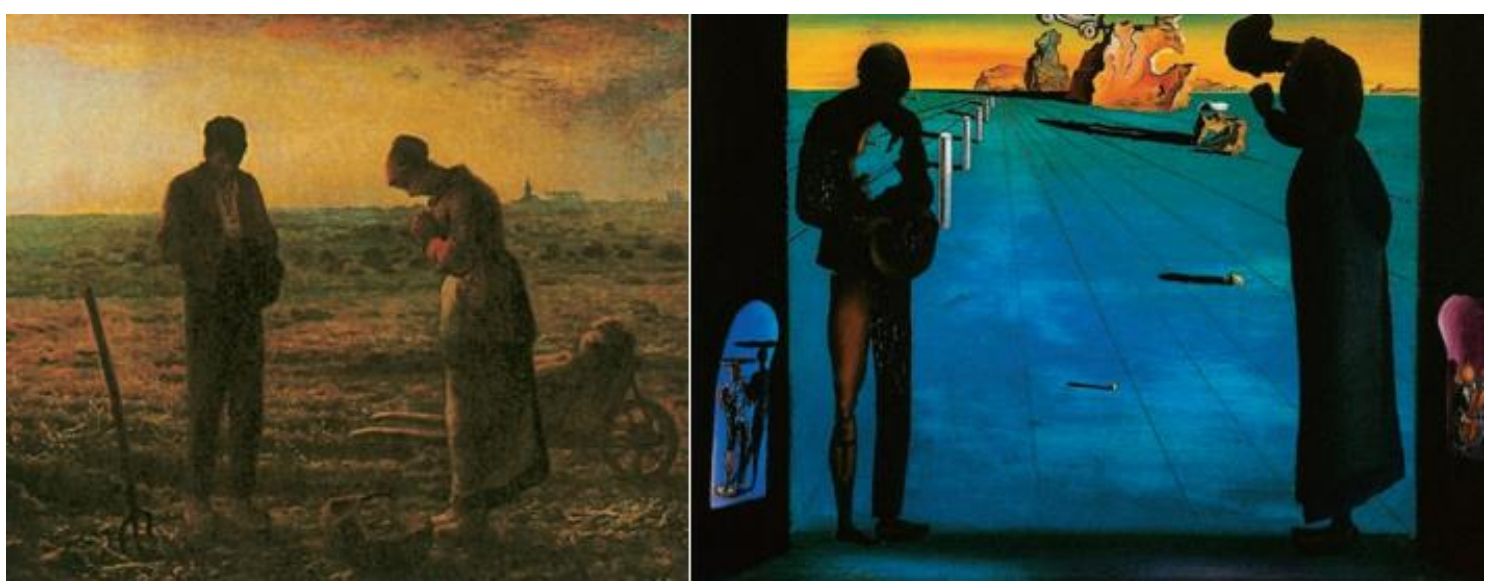

Resim 9. "The Angelus" (1857-59) Jean- François Millet; "Angelus" (1932) Salvador Dali (Shanes, 2011,s.127).

1930'larda Dadaistlerden ilham alan Dali, heykel çalışmalarının (Resim-10) yanı sıra ayakkabılar, bardak, süt, ekmek, telefonlar ve ıstakozlar dahil olmak üzere bulunan nesnelerle üç boyutlu biçimler oluşturmaya başladı. Mevcut nesnelerin tuhaf kombinasyonlarına ek olarak, Dali klasik eserleri gerçeküstü bir dokunuşla yeniden oluşturdu. 1964'te Dali ve arkadaşı Marcel Duchamp, tarihin en tanınmış heykellerinden biri olan Venus de Milo'yu güncellemeye çalıştı. Heykel yapmak, Dali'nin gönülden kucakladığı bir sanat formuydu. Genellikle ılık İspanyol güneşinde en sevdiği Moscato'dan bir kadeh alarak oturuyor ve daha sonra kayıp balmumu yöntemiyle bronz heykellere dökülecek balmumu modelleri yaratıyordu (Shanes, 2011,s.174). Tabi ki hiç kuşkusuz kelebek, ayna, elma, saat gibi imgelerle oluşturduğu Sürrealist resimler eserleri arasında en ünlü olanlarıdır. Bu resimlerde dini metaforlara da yer vermiştir (Resim-11). Belleğin Azmi Tablosu (The Persistence Of Memory), Yanan Zürafa (The Burning Giraffe) (1937), Çiçek Başlı Kadın (Woman With Flower Head) (1937), Atomik Leda Tablosu (1949), Salvador Dali Son Akşam Yemeği Ayini (1955), Picasso Portresi Tablosu (1947), Kelebek Tablosu, Elma ve Kelebek Tablosu, Ayna, St. Anthony'nin Baştan Çıkışı, Narcissus'un Metamorfozu (Metamorphosis of Narcissus), Istakoz Telefon (Afrodizyak Telefon), The Swallow's Tail (Kırlangıç Kuyruğu) en bilindik eserleridir.

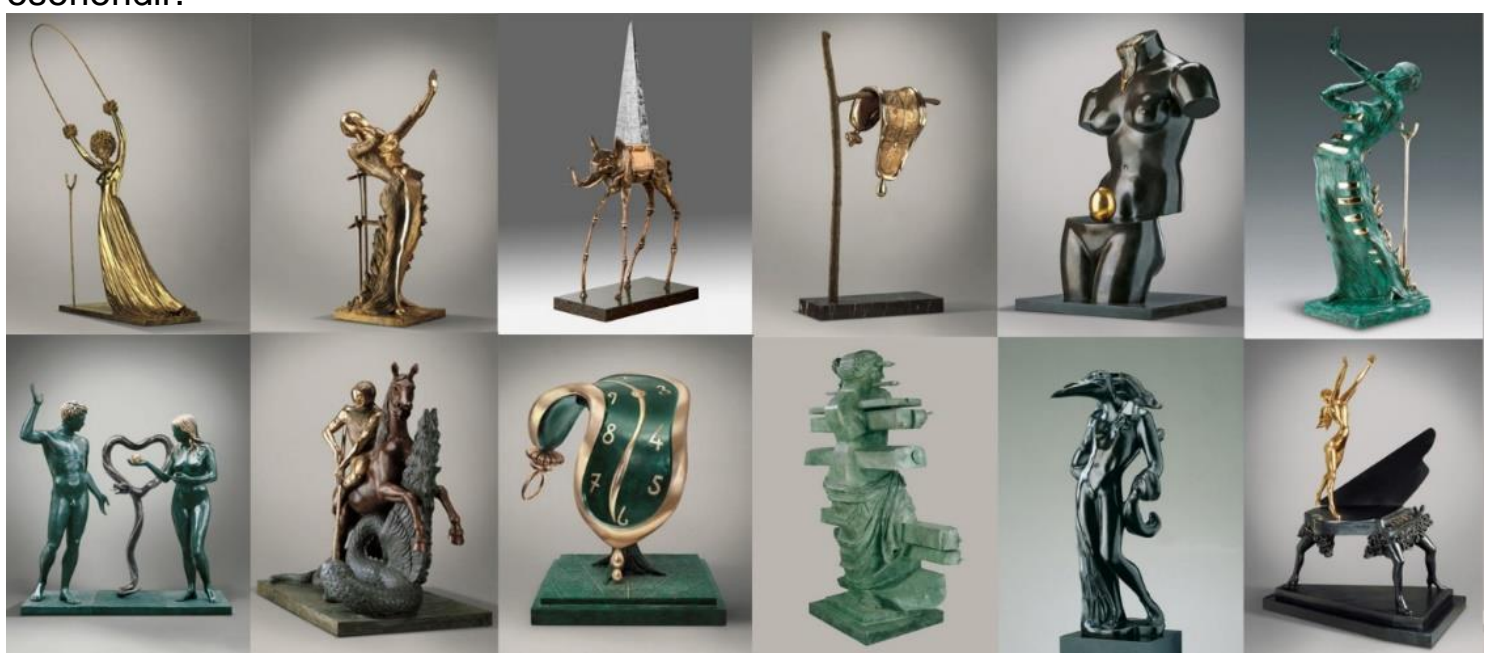

Resim 10. Dali Heykelleri ve Objeleri (URL-7). 


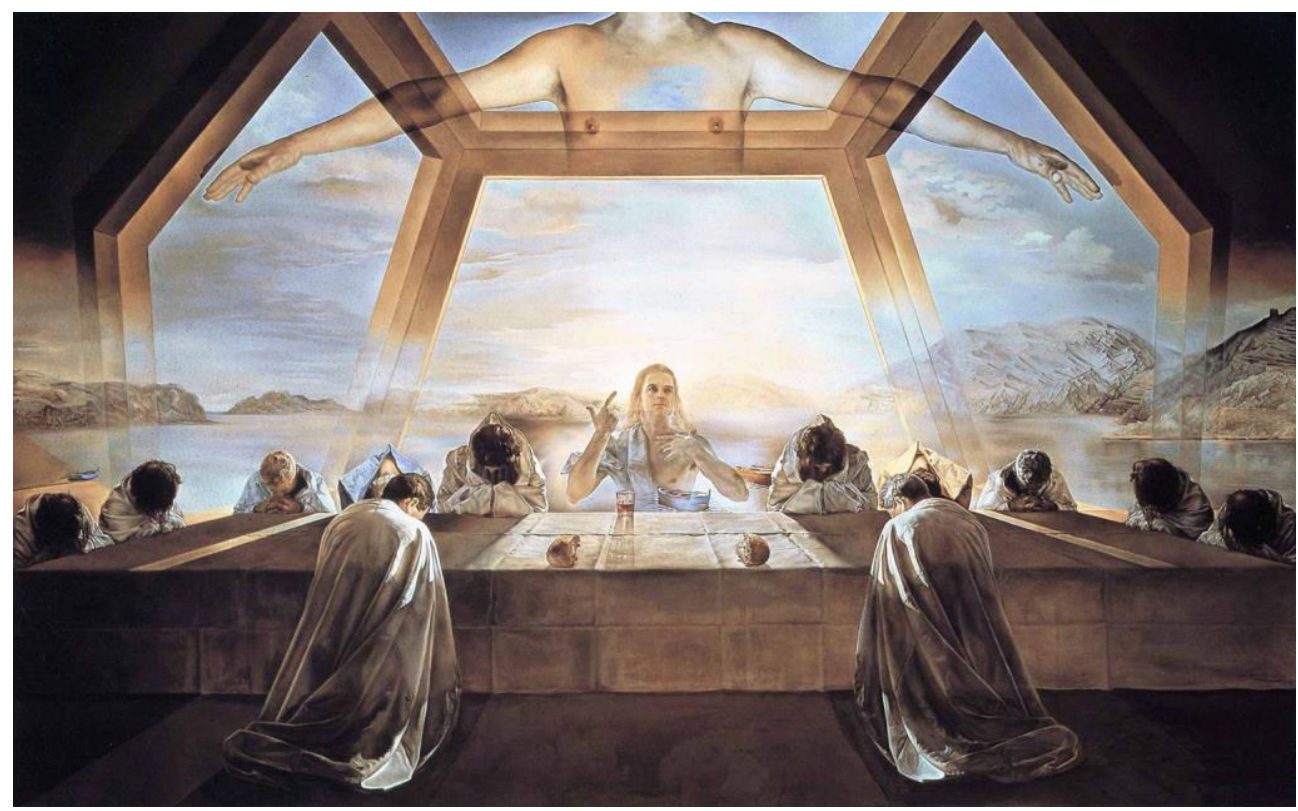

Resim 11. "Son Akşam Yemeği Ayini", 1955 (Shanes, 2011,s.229).

\section{Sürrealizm ve Sürrealist Mobilya}

"Modern sanatın kurtarıcısı olduğuma inanıyorum." Salvador Dali

Türkçe "gerçeküstücülük" olarak tanımlanan Sürrealizm Avrupa'da I. Dünya Savaşı'nın ardından gelişen ve büyük ölçüde Daizm'den etkilenen bir kültürel hareketti. 1920'lerde başlayan ve 30'larda gelişen Fransa kökenli bu hareket, en çok görsel sanat eserleri, yazılar ve imgeler aracılığıyla bilinçdışı zihni harekete geçirmek için uzak gerçekliklerin yan yana gelmesiyle tanınır. "Sürrealizm" terimini ilk kez 1917 yılında şair, yazar ve sanat eleştirmeni Guillaume Apollinaire'in kullanmasına rağmen Sürrealist hareket, Fransız şair ve eleştirmen André Breton'un Paris'te Sürrealist Manifestosu'nu yayınladığı 15 Ekim 1924'e kadar resmiyet kazanmamıştır. 1920'lerden itibaren hareket tüm dünyaya yayılmış ve birçok ülkenin görsel sanatlar, edebiyat, sinema, müzik, siyasi düşünce ve pratiği, felsefe, sosyal teori ve daha birçok alanı etkilemiştir.

Sanatçılar sıra dışı, biraz da sinir bozucu, mantıksız sahneler kullanarak bazen fotoğrafik bir hassasiyetle boyayarak resimlerini oluşturmuş, gündelik nesnelerden garip yaratıklar yapmış ve bilinçdışının kendini ifade etmesine izin veren boyama teknikleri geliştirmişlerdir. Hareketin lideri André Breton'un 1924'deki Sürrealizm Manifestosuna göre bu hareketin amacı, "daha önce çelişkili olan rüya ve gerçeklik koşullarını mutlak bir gerçekliğe, bir süper gerçekliğe" veya gerçekliğe dönüştürmekti (Chilvers, 2009,s.611). Andre Breton bu konuda; "Gerçeküstücülük, ister söz, ister yazı ile ya da başka bir yolla, düşüncenin gerçek işleyişini ortaya çıkarmak için başvurulan, içinden geldiği gibi yazma yöntemidir. Bu, aklın denetimi olmaksızın (rüyada olduğu gibi) her türlü estetik ve ahlak kaygısı dışında düşüncenin yazılışıdır." İfadesini kullanmıştır. Bu bildirgede düşüncenin aklın denetimi olmadan ve ahlak gibi engelleri hiçe sayarak ortaya konmasını savundular. Eserlerinde nesneleri alışılmamış biçimlerde betimleyen gerçeküstücü sanatçılar, çoğunlukla düşlerin gizli dünyasını dile getirmeye çalıştılar. Bazen de nesneleri kendi doğal ortamlarından çıkartarak düşsel bir ortama taşıdılar (Breton, 1997, s.47; Edwards, 2009,s.88). 
Sürrealizm eserleri, sürpriz, beklenmedik yan yana gelmeler ve ardışık olmayan unsurlara sahiptir. Bununla birlikte, birçok Sürrealist sanatçı ve yazar çalışmalarını her şeyden önce felsefi hareketin bir ifadesi olarak görmektedir. Breton, Sürrealizmin her şeyden önce devrimci bir hareket olduğu iddiasında bulunmaktaydı. O zamanlar hareket, komünizm ve anarşizm gibi politik nedenlerle ilişkilendirildi. Dali'nin siyasi ve politik kimliği de bu ilişkilendirmede etkili olmuştur (Breton, 1997, s.47). Giorgio de Chirico, Max Ernst, Man Ray, Joan Miró, René Magritte, Victor Brauner ve Salvador Dalí bu üslubun önemli temsilcileri arasındadır (Resim-12).

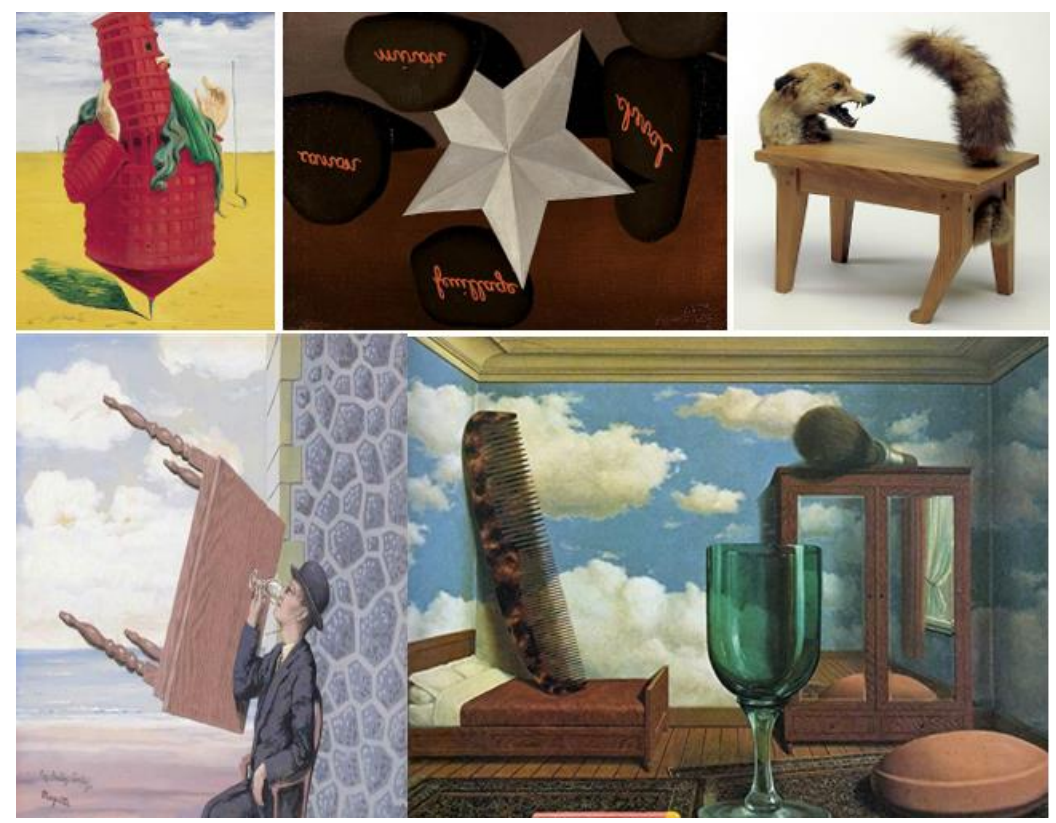

Resim 12. "Ubu Imperator", (1923), Marx Ernst; "Querelle des Universaux", (1928), René Magritte; "Wolf-table", (1939-1947), Victor Brauner (URL-8), "Man Seated at Table" ve "Personal Values" Tabloları René Magritte.

Özetle, Sürrealizm, aklın, mantığın, geleneklerin, alışkanlıkların denetiminden uzak, bilinçaltı gerçeklerini yansıtan bir gerçek yaratmayı amaçlayan bir sanat akımıdır. Düşüncenin gerçek faaliyetini ifade eden saf ruhî bir otomatizmdir ${ }^{3}$. İmla kuralları ve noktalamadan uzak otomatik yazı, mizah, hariküladecilik, rüyalar, çılgınlık, çocukluk yıllarına dönüş bu sanat kapsamında üretilen eserlerin önemli özellikleridir. Sürrealistler alaycı, mizaha öykünen kural ve sıra dışı çalışmalarında rüyalara dayanan çılgın eserler ortaya koyarken bu eserler insan aklı ve mantığının gerçek diye ortaya koyduğu değer ve doğruları aşma eyleminde olduğu için harikulade olma özelliği de göstermektedir.

Dali yönünden sürrealizm, rüyalar ve bilinçaltı olgular dünyasına biçim vermeye çalışmaktır. İnsan zihninin bu bilinmeyen yönünün sanatsal analize elverişli olduğu düşünülmektedir. Dali'nin sürrealist sanatçı grubu ile ilişkisi gün giderek yoğunlaşmıştır. Başlangıçta bu grup Dali için ciddi bir entelektüel rol oynamıştır. Bu konu hakkında Dali şöyle ifade etmiştir: "Onun bana ikinci kez doğmak gibi bir şey sunduğunu düşünüyordum. Sürrealist grup benim için besleyici bir bitki gibiydi ve Sürrealizme "on Emir'e inanır gibi inanıyordum. Aklımın ruhu, benim en derin varlığıma tıpatıp uyuyordu. Aslında ben sadece, bilinçaltımın bana emrettiklerini, yani hayallerimi, uykuda gelen imgeleri ve görüntüleri, Freud'un keşfettiği karanlık ve sansasyonel dünyanın her türlü somut ve usdışı görüngülerini hiç yargılamaksızın ve mümkün

${ }^{3}$ Özdevinim 
olduğunca eksiksiz bir biçimde kayda geçiren bir otomattan ibaretim... Kamuoyu böyle imgelerin izleyenin bilinçaltında uyandırdığı sonsuz gizem, muamma ve ıstırap kaynaklarının zevkine varmaktır." Bu ifade Dali'nin o andan itibaren uygulamaya başladığı yöntem konusunda yol göstericidir (İstanbul'da Bir Sürrealist Salvador Dali Sergi Kitapçığı, 2008,s.11).

Breton ise Dali'nin Sürrealizmi birincil önem taşıyan bir araçla donattığını, bilhassa paranoyak eleştirel metodun resme, şiire, sinemaya, tipik sürrealist nesnelerin oluşumuna başarıyla uygulanabilir olduğunu söylemiştir. Dali, 1930'ların başında keşfettiği özel dil ve ifade biçimini hayatı boyunca bırakmadı. Bu üslup avangart ile geleneği harmanlayarak insanı mükemmelden tanımlamaktaydı. Dali Sürrealizmde kendi doğasını bulmuştur. Dali Time Dergisi'ndeki " Sürrealist Deneyde Ortaya Çıkan Obje" isimli makalesinde şöyle ifade etmiştir: "Nesne bizim dışımızda, bizim bir rolümüz olmadan var olur (antropomorfik nesneler); nesne arzunun kararlı biçimini alır ve düşüncemizi etkiler (rüya hali nesneleri); nesne hareket ettirilebilir; öyle ki üzerinde etki yapılabilir (sembolik işlevli nesneler); nesne onunla birleşmemizi sağlamaya eğilimlidir ve bizi kendisiyle bir birlik oluşturma peşinde koşmaya iter (nesneler ve yenebilir nesneler için açlık duymak) (İstanbul'da Bir Sürrealist Salvador Dali Sergi Kitapçığı, 2008,s.13).

Mobilya alanında da önemli örneklerin verildiği bu üslup 20. Yüzyıl başlarından itibaren günümüze dek mobilya tasarımında etkili olmuştur. Sürrealist mobilyanın temel ilkeleri arasında kesintisiz yüzeyler, hipertrofik ${ }^{4}$ olma, beklenmeyen formlar ve materyallerin kullanımının bir kombinasyonu olma yer almaktadır. Sürrealizm mobilyada var olduğunda, fantezinin ve düşler âleminin harfiyen temsile dökülmesi biçimini alır ki bu, kitsch'e tehlikeli biçimde yaklaşımdır (Resim-13). Gündelik nesnelerin kullanımı ile zenginleşen mobilyaların çevreci yaklaşımlara da katkısı olduğu söylenebilir. Sürrealist mobilyayı Dali'nin mobilya ile ilişkisini inceleyerek daha iyi anlamak mümkündür.

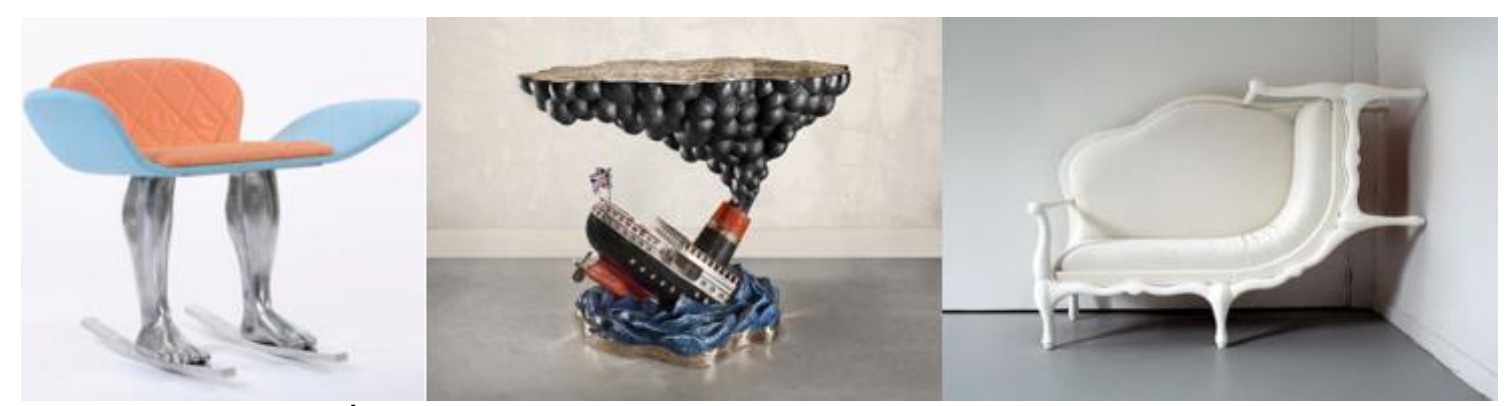

Resim 13. Sürrealist İskemle, Tasarım: David Pompa (2008), Sürrealist Sehpa, Tasarım: Studio Job (2016) (URL-9), Sürrealist Koltuk Tasarım: Lila Jang (URL-10).

\section{Dali'nin Eserlerinde Mobilya Metaforu}

"Gerçek bir ressam

En sıradan şeyler karşısında En sıra dışı fikirleri üretebilen kişidir."

Salvador Dali.

Gerçeküstücülüğün temelleri yalnızca hayali, muhteşem imgeleme temalarına değil; aynı zamanda yanıltıcı akıl yürütme dünyasına da dayanıyordu. Sürrealistler, görsel paradoks sanatı yoluyla zihne meydan okumak için düzenli olarak imgelemeyi

\footnotetext{
${ }^{4}$ Hipertrofi bir doku ya da organın aşırı gelişmesi olarak tanımlanır. Sanatta belli bir biçimin ya da parçanın abartılarak çizilmesi olarak tanımlanır.
} 
kullandılar. Muhtemelen avangart kültürel hareketin figürü olan Salvador Dalí, sembolik ve yanıltıcı başların ve yüzlerin düzenli kullanımı da dahil olmak üzere, üretken eserleri boyunca tekrar tekrar ortak bir konuyu kullandı. Dali'nin eserlerinde metaforlar evreni hayal gücünün sınırlarını zorlamakla kalmamakta, izleyenlerin algı biçimlerini de etkilemektedir. Dali'nin eserlerinde çılgın bir düş gücü ile algı biçimini resme dökebilme dehası bir araya gelmiştir.

Dali garip dünyasının sisli olaylarını, objelerini, yaratıklarını her türlü mantık düzeninden uzak tablolarında canlandırmaktaydı. Kadın vücudundan çıkan çekmeceler, çölde yanan zürafalar, sahilde dikiş makineleri, yataklar gibi birbiriyle ilgisiz birçok nesne ilgisiz mekânlarda resmedilmekteydi. Dali'nin kuğular, doldurulmuş hayvanlar (tahnitçilik) ve yumurtalara karşı bir takıntısı vardı. Yumurtalar yeniden doğuşu simgelemiştir. Dali eserlerinde sanatına sık sık saatleri de dahil etmiştir. Bu temalar, insanların yaşlanma korkusundan ve sevdiğimiz kişilere tutunma isteğinden kaynaklanmaktadır. İlk bakışta tuhaf görünen şeyler, eserlerinin arkasındaki sembolizmi anladıktan sonra aslında oldukça anlamlıdır.

Esasen, Dali'nin eserlerinin en önemli özelliği gerçekliği karmaşık hale getirmesidir. Bu karmaşıklıkla aslında eski anılarına dayanan hikayeler anlatmaktadır. Yukarıda anlatıldığı gibi hayvanlar, nesneler, mobilyalar, manzaralar eşliğinde eserlerini oluşturmuştur. Sıra dışı eserlerinde bilhassa mobilyalar dikkati çekmektedir. Mobilyaları çoğu zaman geçmiş yaşamındaki insanlar ve anılarla özdeşleştirmiştir. Örneğin; "The Weaning of Furniture-Nutrition" (1934) isimli tablosunda bulunan çekmeceli komodinler ve hemşire figürü incelendiğinde; hemşire çocukluğundaki bakıcısını hemşireden çıkan çekmeceli komodinler de bakıcısı ile olan çocukluk anılarını temsil etmektedir. Çekmeceler hem birçok resminde hem de heykel çalışmalarında kullanılmıştır. Çekmece bilinçaltındaki anıların gruplandığı bölümleri temsil etmekteydi (Resim-14).
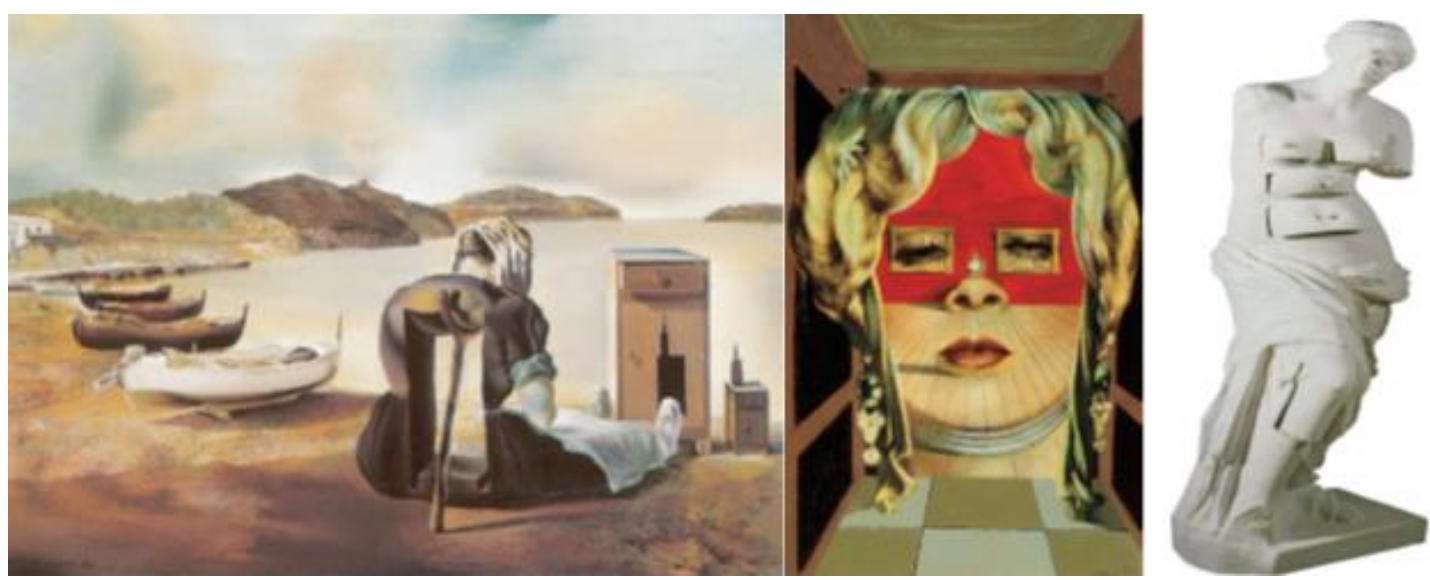

Resim 14. "The Weaning of Furniture-Nutrition" (1934) ve "Mae West Room" (1934-35), Venus de Milo (1936) İsimli Eserleri. .

Mae West'in yüzünden esinlenerek oluşturduğu iç mekân ve bir görsel illüzyon çalışması olan "Mae West Room" isimli eseri mobilya ve sanatı arasında kurmuş olduğu ilişkinin geldiği en üst nokta denilebilir. Sadece Dali'nin eserlerinde değil; diğer sürrealist sanatçıların eserlerinde de mobilya metaforunu görmek mümkündür. Örneğin; René Magritte'nin eserlerinde yatak, dolap, masa gibi mobilyalar uykudan uyanma evresindeki bilinçdışı durumu büyüleyici bir biçimde yansıtmaktadır. Sanatçı, gerçekçi ve doğrucu bir yaklaşımla betimlenmiş, kolayca tanınan bu sıradan nesnelerin görüntülerini, kendi doğal çevrelerinden çıkartıp, usa ters düşen, şaşırtıcı, düşsel bir ortam içinde vermiştir. Gerçeklik duygusu yaratan ip uçlarını bilerek yanlış kullanıp, 
görünen dünyanın gizeminden kaynaklanan şok ve sürprizleriyle insanları geleneksel görme alışkanlıklarından özgürleştirip, us ve mantık dışını anlamaya zorlamaktadır. "Personal Values" isimli yapıtında nesneler uzaydaki yerleriyle uyumsuz büyüklüktedir (URL-11) (Resim-12).

\section{Dali ve Mobilya}

"Mükemmelden korkmayın nasılsa ona ulaşamayacaksınız."

Salvador Dali

Eserlerinde metafor olarak kullandığı mobilyaları günlük yaşamda kullanılan nesneler olarak da tasarlayıp üreten Dali, bu mobilyaların bazılarını resimlerinde de imge olarak kullanmıştır. Hemen her alanda eser üreten ve kendisini delilik ile normallik arasındaki ince çizgide kabul eden sanatçının (Dali, 1948,s.3) önemli mobilya tasarımları bulunmakta, bu mobilyalar halen daha üretilmekte ve iç mekânlarda tercih edilmektedir. Dali'nin çok sayıdaki illüstrasyon, eskiz ve tablosunda mobilya fikirleri ürettiği de görülmektedir (Resim-15). Ayrıca mobilya kullanarak ürettiği sanat eserleri de bulunmaktadır (Resim-15, 16, 17).
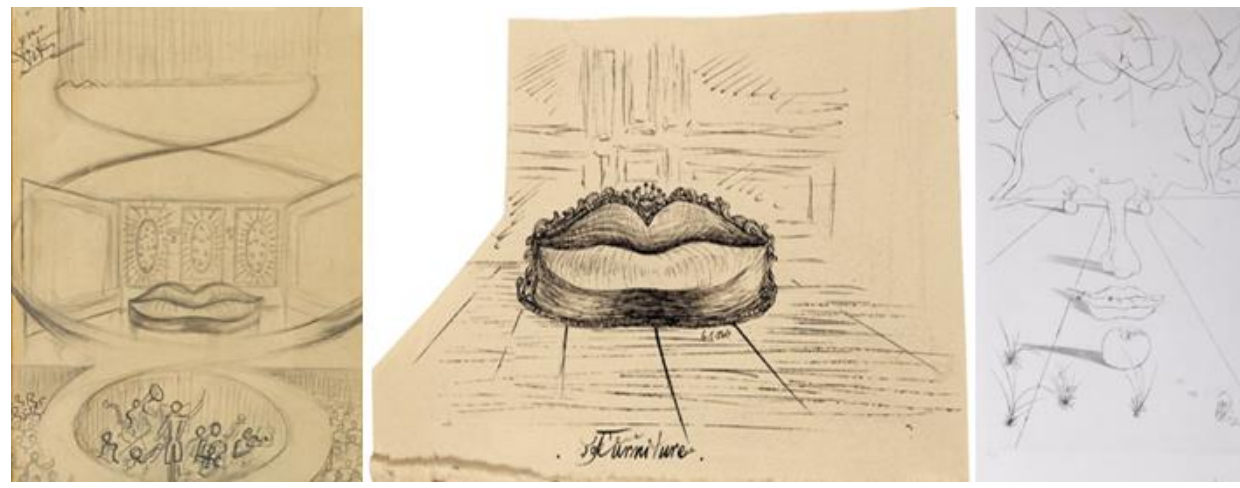

Resim 15. "Théâtre et Scène Saliva Sofa", 1937, "Furniture” 1939, Surrealistyczna Twarz

(Aurelia), 1972 (URL-12).
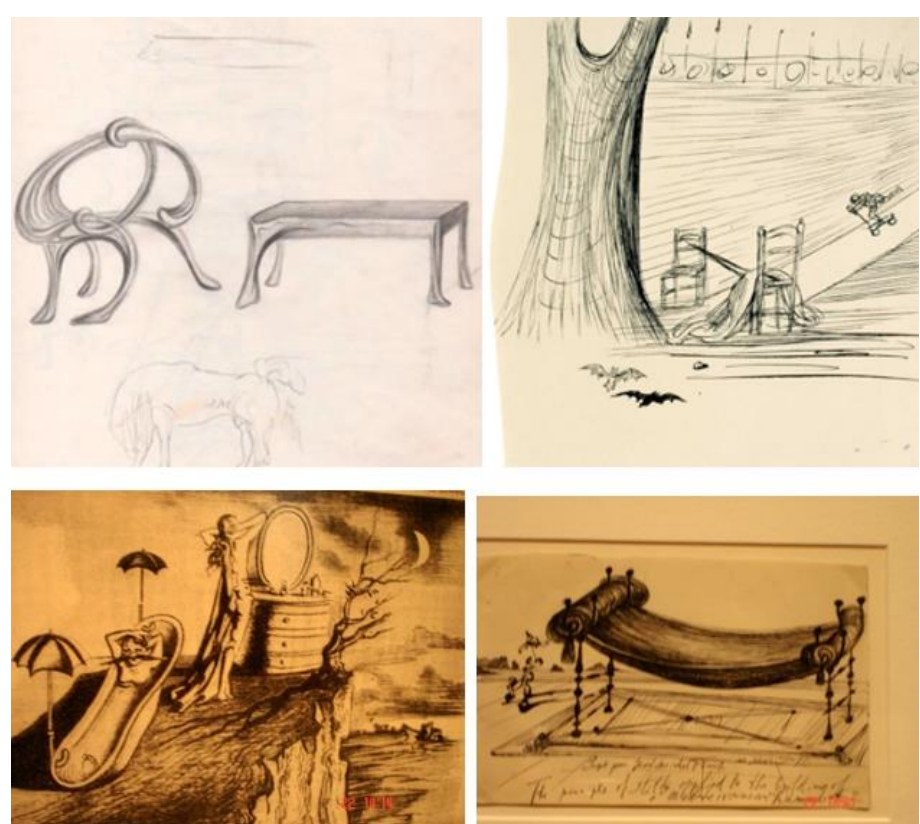

Resim 16. “Furniture Study/ Mobilya Çalışmaları” illüstrasyonlar, 1936 ve 1939, (Demirarslan, 2008) (URL-12). 


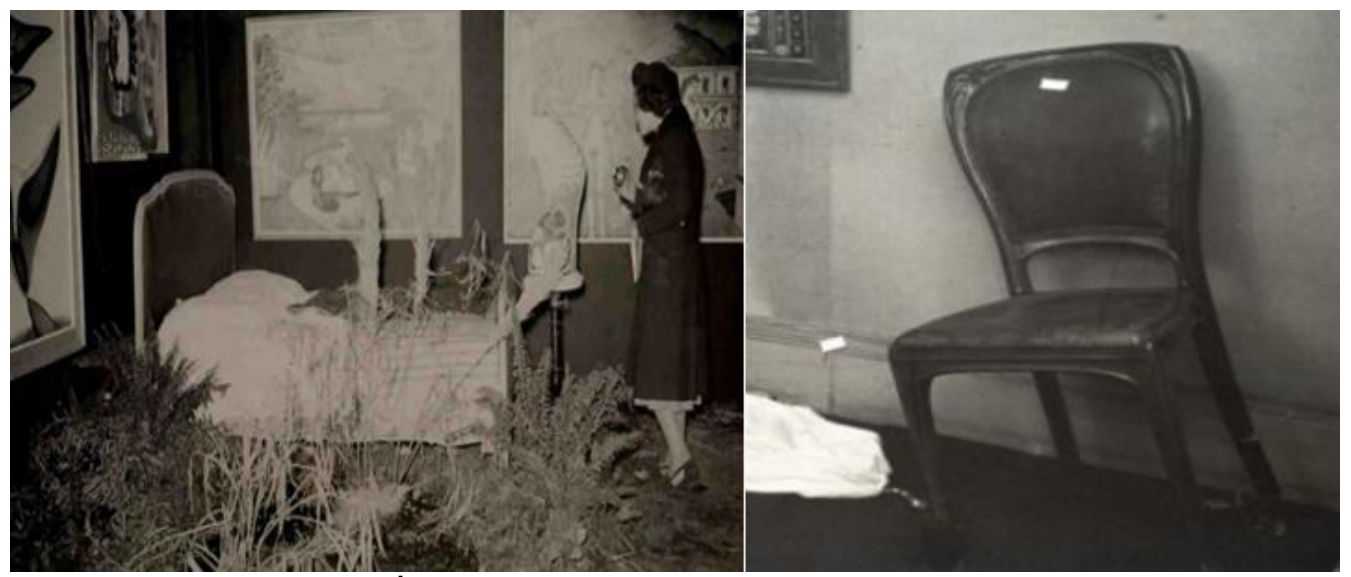

Resim 17. 1938 Paris Sergisi İçin Yaptığı Yatak Odası ve Orman Temalı Enstalasyon Çalışması (Anderson, 2002,s.19), "Atmospheric Chair/ Atmosferik İskemle" (1933) (URL-13).

1938 yılında Paris Sergisi için yatak kullanarak bir enstalasyon çalışması ortaya koyarken; "Atmospheric Chair- Atmosferik İskemle" (1933) sanatçının arkadaşı dekoratör Jean-Michel Frank tarafından kendisine hediye edilen 1900'lü yıllara ait iki iskemleyi dönüştürerek yaptığı "dengesiz bir denge" olarak tanımladığı bir sanat eseridir (Descharnes \& Nerret, 1989, s.73). Dali mobilyayı gündelik eşyadan ziyade bir sanat eseri olarak görmekteydi (Resim-17).

Tasarladığı mobilyalar ve özelliklerine geçmeden önce sanatçının yaşadığı evindeki mobilyalara ve gündelik eşyalara göz atmak tasarımlarını ve sanatını yönlendiren yaşamı hakkında bilgi edinmek gerekir.

\subsection{Dali'nin evinde yaşam ve mobilyalar}

Dali, 1982 yılında eşi Gala ölünceye kadar Port Lligat'daki evinde yaşamıştır. Ev kendi dokunuşları ile biçimlenen eşya ve mobilyalar ile halen ilk günkü gibi korunmaktadır ve günümüzde bir müze olarak hizmet vermektedir. "Bir Dahinin Güncesi" isimli kitabında eşi Gala'nın evlerindeki mobilyaların büyük bir kısmını mobilyaları ile ünlü Olot kasabasından satın aldığını belirtmiştir (Dali, 1991, s.76).

Giriş mahallinde Dali'nin biçimlendirdiği ayı şeklinde bir vestiyerin yer aldığı evin, oturma odalarından biri olan "The Yellow Room/ Sarı Oda" L şeklinde sarı kadife kumaştan bir oturma elemanı yer aldığı için bu isimle anılmaktadır (Resim-19). Dali'nin en sevdiği evinde sedir tarzı oturma elemanları yemek ve oturma odalarında kullanılmıştır. İşlevsel bir oturma elemanı olan sedirlerin Le Corbusier'in Türk Evi'nden esinlenmesinde olduğu gibi Doğu mimarisinin özelliklerinden esinlenmiş olabileceğini düşündürmektedir. Gibson eserinde Dali'nin İspanya'yı fethetmiş olan Mağribilerin soyundan geldiğini iddia ettiğini, "süslü ve cafcaflı olan her şeye, lüks hayata ve doğu kıyafetlerine olan düşkünlüğünü" de "Arap kökeni"ne dayandırdığını belirtmiştir (Gibson, 1997, s.28). Dali'nin cafcaflı görünüşüne önemli bir örnek Ara Güler tarafından çekilmiş fotoğrafıdır. Dali, Barok tarzı bir koltukta oturarak poz verdiği bu fotoğrafı için şimdiye kadar kendisini en iyi şekilde yansıtan fotoğraf karesi şeklinde yorum yapmıştır. Kendi evinde bir başka fotoğraf sanatçısı tarafından çekilen fotoğrafında yine Barok tarzı bir mobilya ile ilişkisi ön plandadır. Bahçede çekilmiş bir başka fotoğrafta ise değişik bir oturma elemanı üzerinde poz vermiştir. Muhtemeldir ki bu, sanatçının tasarladığı bir oturma mobilyasıdır (Resim-18). 


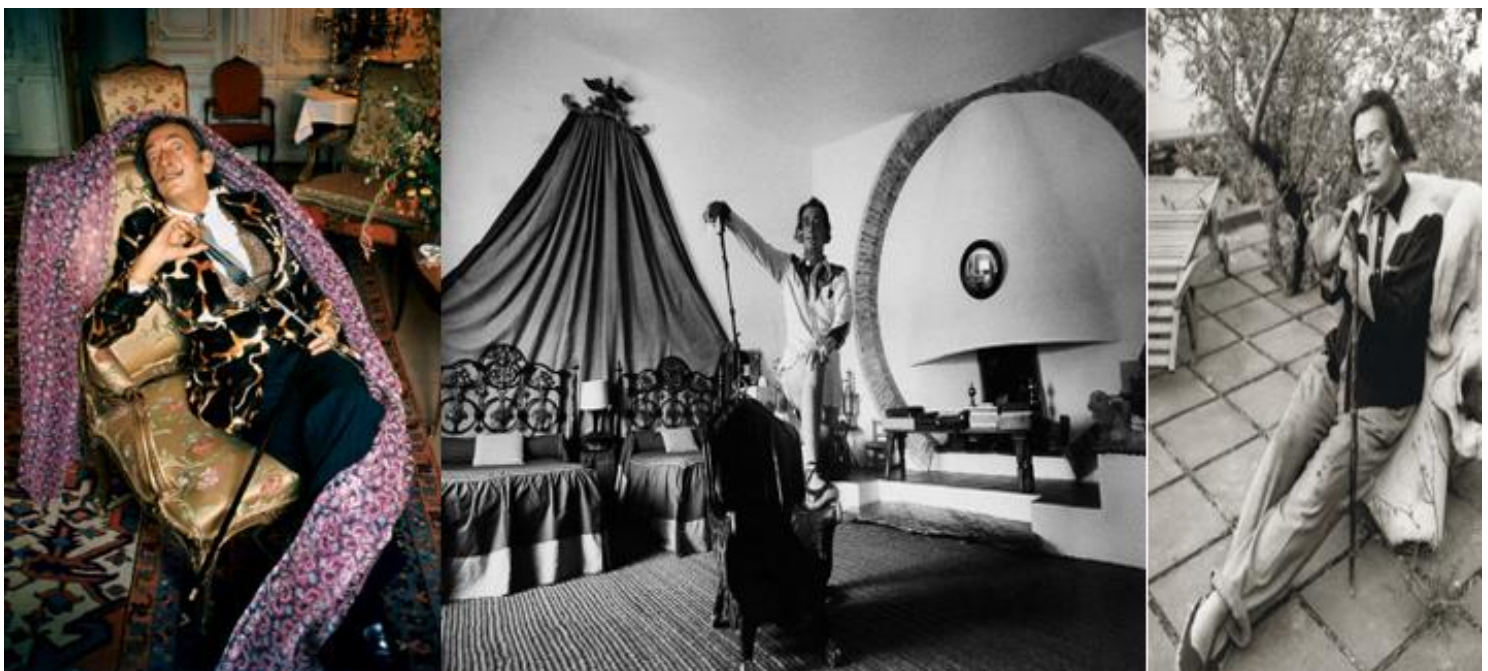

Resim 18. Ara Güler tarafından Çekilen Dali Fotoğrafı (URL-14), Salvador Dali Yatak Odasında, Cadaqués, 1963 (URL-15), Bahçesinde Poz Veren Dali (URL-16).

Yerde Doğu işi bir halının serili olduğu oval planlı oturma odası karşılıklı iki duvarda sedirle çevrilmiş ve ortada bir şömine görünümünde kalorifer peteği vurgulanmıştır (Resim-19). Benzer şekilde yemek odası da $U$ şeklinde taş malzemeden bir oturma sediri ve önünde bir masa ile donatılmıştır. Benzer taş sedirler bahçede de görülmektedir. Süslü, cafcaflı iç mekân ve mobilya anlayışını evin yatak odasında çok daha baskın bir şekilde görmek mümkündür. Stüdyosu başta olmak üzere evin muhtelif köşelerinde resimlerinde sıklıkla kullandığı iskemlenin farklı büyüklüklerde çeşitleri bulunmaktadır (Resim-18). Dali resimlerinde imge olarak iskemle çizerken evindeki iskemleleri mi model olarak alıyordu? Yoksa bu tip iskemleler çocukluğundaki evi hatırlattığı için mi hem evinde hem resimlerinde bu tarz iskemleleri kullanıyordu?
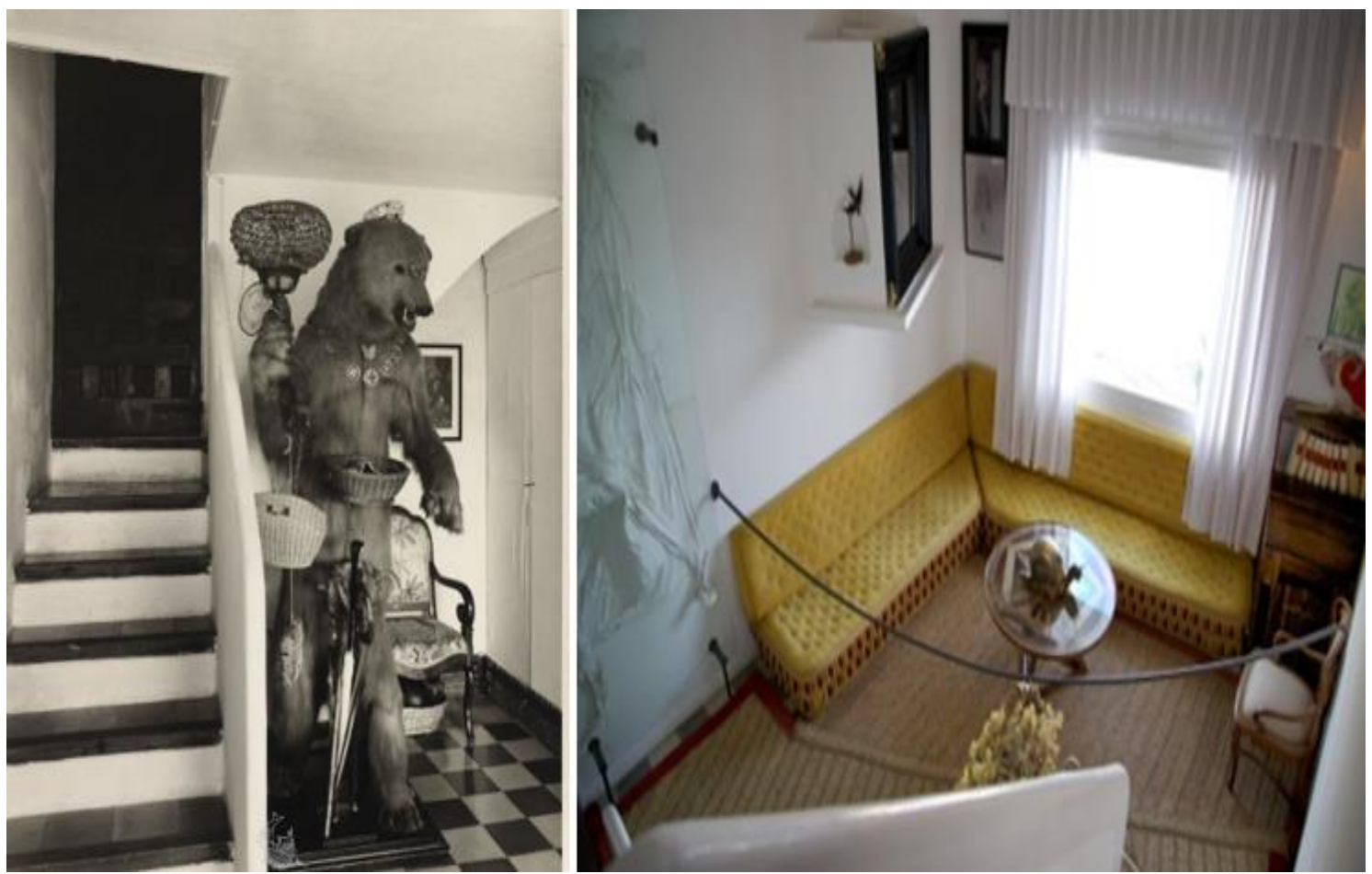

Resim 19. Port Lligat'daki Evinin Giriş Holünde Bir Ayı Heykeli Aynı Zamanda Bir Vestiyer Görevi Görmektedir, Tasarım: Salvador Dali. (URL-13). "The Yellow Room/ Sarı Oda” (URL-17). 


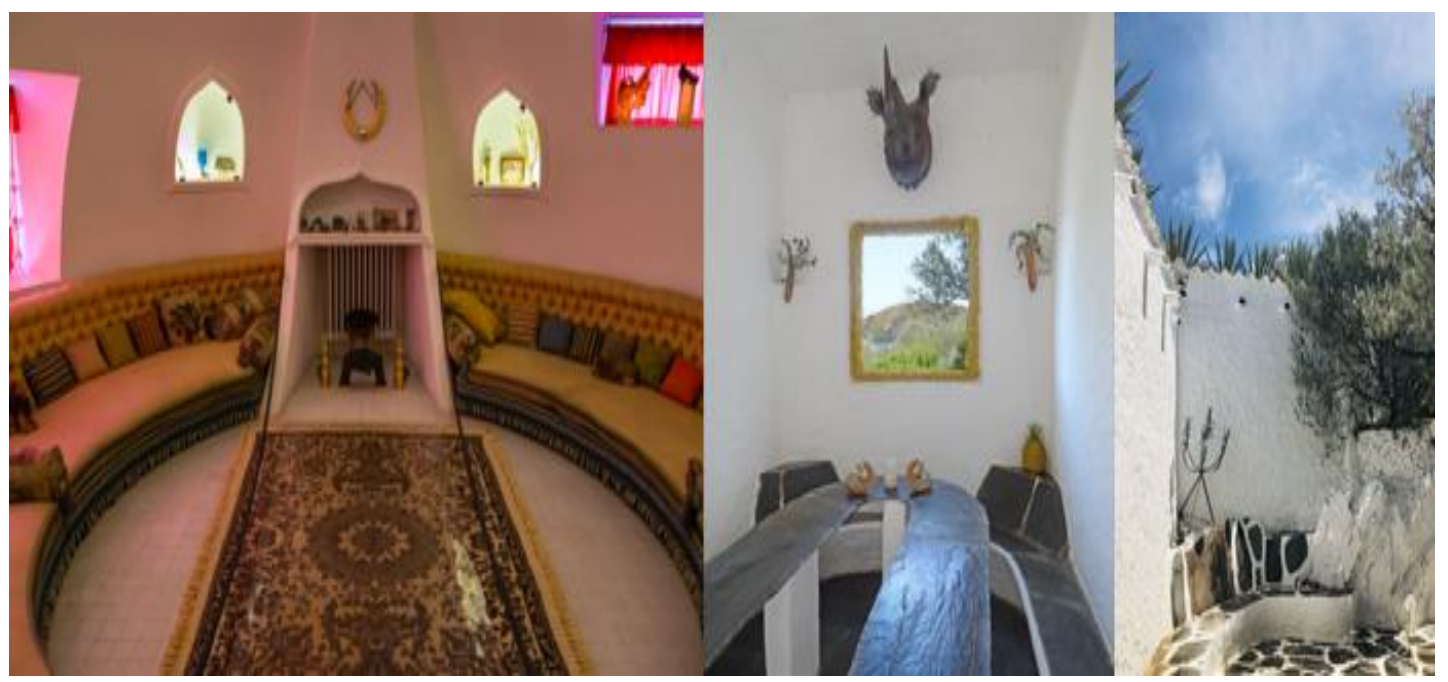

Resim 20. Oturma Odası ve Yemek Odası Mobilyaları (URL-18; URL-19).

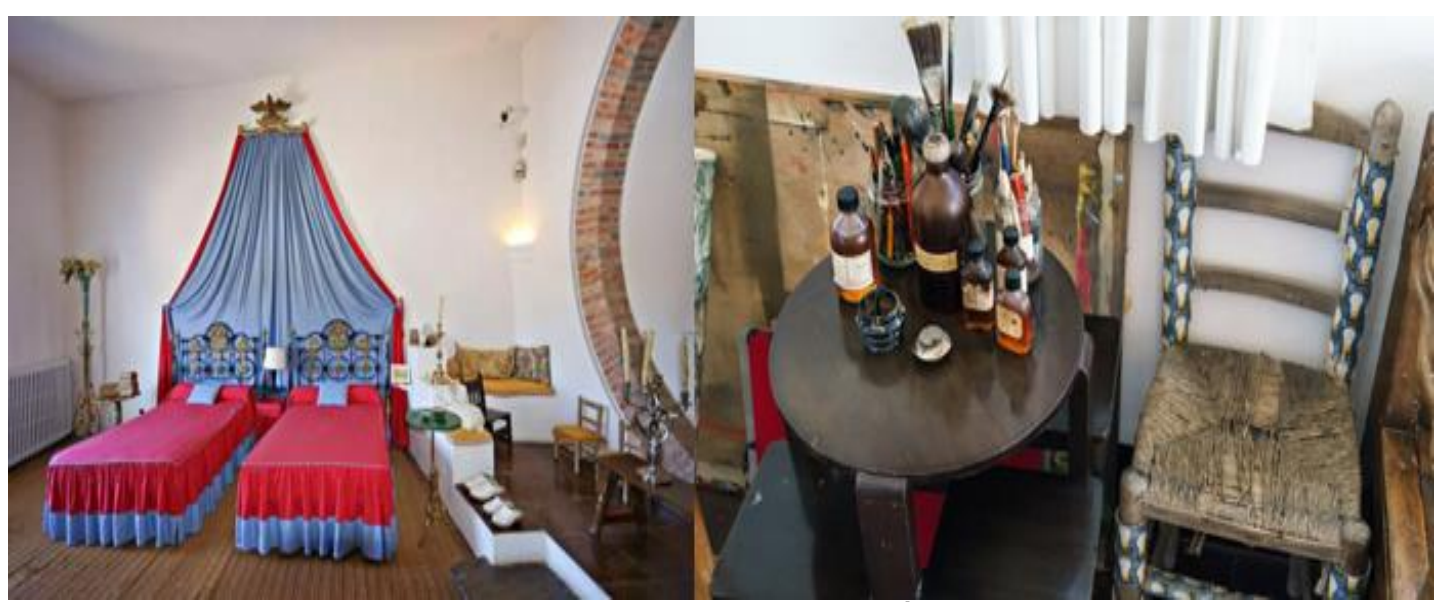

Resim 21. Yatak Odası ve Stüdyosundan İskemle (URL-19).

\subsection{Dali'nin tasarladığı mobilyalar}

Bu mobilyaların içinde en bilineni "Dalilips" olarak isimlendirilen ve ünlü film yıldızı Mae West'in dudaklarından esinlenerek tasarladığı koltuktur. Bu koltuğu ilk olarak "Mae West'in Odası/ Mae West Room" isimli çalışmasında kullanmıştır. Bu koltuk, 1972'de Salvador Dalí tarafından mimar Oscar Tusquets ile birlikte yeniden üretilmiş ve TeatreMuseu de Figueras'ın Mae West odası için tasarlanmıştır (Resim-22). 2004 yılından beri dış mekân kullanımına uygun rotomoldlu ${ }^{5}$ polietilenden üretilmektedir. Tusquests anılarında şöyle demiştir: "Ona göre plastik harikaydı, Pop Art idi." (URL-20). Blanca bir röportajında Dali için "Ondan sıkılmak imkansızdı. O her zaman heyecan verici, çok zekiydi” şeklinde bir açıklamada bulunmuştur (URL-21). Dali, Blanca'nın da ifadesine göre; "Mae West'in Odası" tablosundan önceki dönemlerden ölene dek farklı zamanlarda bu koltuğu eskiz ve illüstrasyonlarında sayısız kez çizmiştir (Resim-12).

\footnotetext{
5 Rotasyonel kalıplama: ayrıca dönel kalıplama, döner kalıplama, rotasyonel kalıplama, rotatif döküm, rotatif şekillendirme, vb. Olarak da adlandırılır. Rotasyonel kalıplama işlemi ilk önce kalıbın içine plastik hammaddeler ekler ve daha sonra kalıp sürekli olarak döndürülür ve iki dikey eksen boyunca ısıtılır. Kalıptaki plastik hammaddeler kademeli olarak eşit şekilde kaplanır ve eritilir ve yerçekimi ve ısı enerjisi etkisi altında kalıba yapıştırılır. Boşluğun tüm yüzeyi istenen bir şekle getirilir ve daha sonra bir ürün oluşturmak için soğutulur.
} 

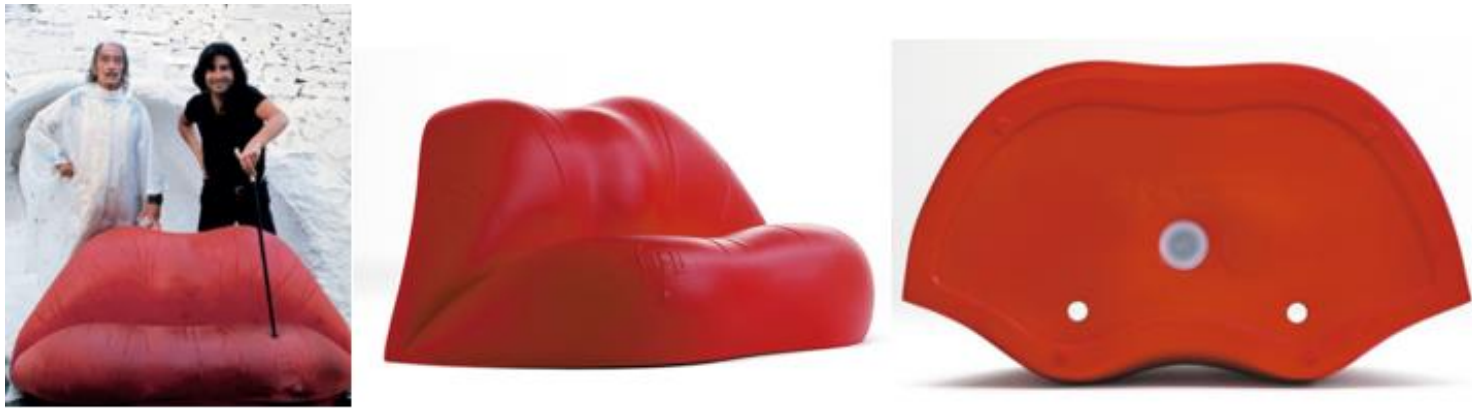

Resim 22. Mimar Oscar Tusquets ve Dali Tasarlayıp Ürettikleri Prototip ile Birlikte (URL-22),

"Dalilips"in Çeşitli Açıllardan Görünümü (URL-23).

Ancak, bu koltuğun çeşitli dönemlerde farklı malzeme ve konstrüksiyonlar ile değişik versiyonlarını tasarlayarak üreten Dali bu koltuk ile neredeyse özdeşleşmiştir. Bunlardan biri 1936 yılında Edward James ile birlikte tasarladığı "Mae West Lips Sofa"dır (77 x 205,7 x $96 \mathrm{~cm})$. Yeşil yün aplikeli ve siyah yün saçaklı kırmızı ve yeşil Melton ${ }^{6}$ yün kumaş döşemesiyle bu kanepenin ilk versiyonunu oluşturmaktadır. 1936 yılında aynı kanepeyi ahşap karkas üzerine kırmızı ve beyaz saten kumaş kaplama ile yeniden yapmıştır $(221,5 \mathrm{~cm})$ (URL-24). Bir diğer örnek; 1938 yılı yapımı masif ahşap konstrüksiyon üzerine pembe saten kumaş kaplı "Sofa in the Form of Mae West's Lips/ Mae West'in Dudakları Şeklinde Kanepe"dir (86,5 x 183 x 81,5 cm). Mae West'in adını taşıyan bu kanepeler hakkındaki düşünceleri de ne yazık ki bilinmemektedir. Bir başka versiyon da "Mae West Lips Sofa/ Mae West'in Dudakları Kanepe" (1936/37)dir. Ahşap konstrüksiyon üzeri pembe keçe ile kaplanmıştır ( $92 \times 213 \times 80 \mathrm{~cm}$, Green and Abbott Firması tarafından üretilmiştir) (Resim-23).

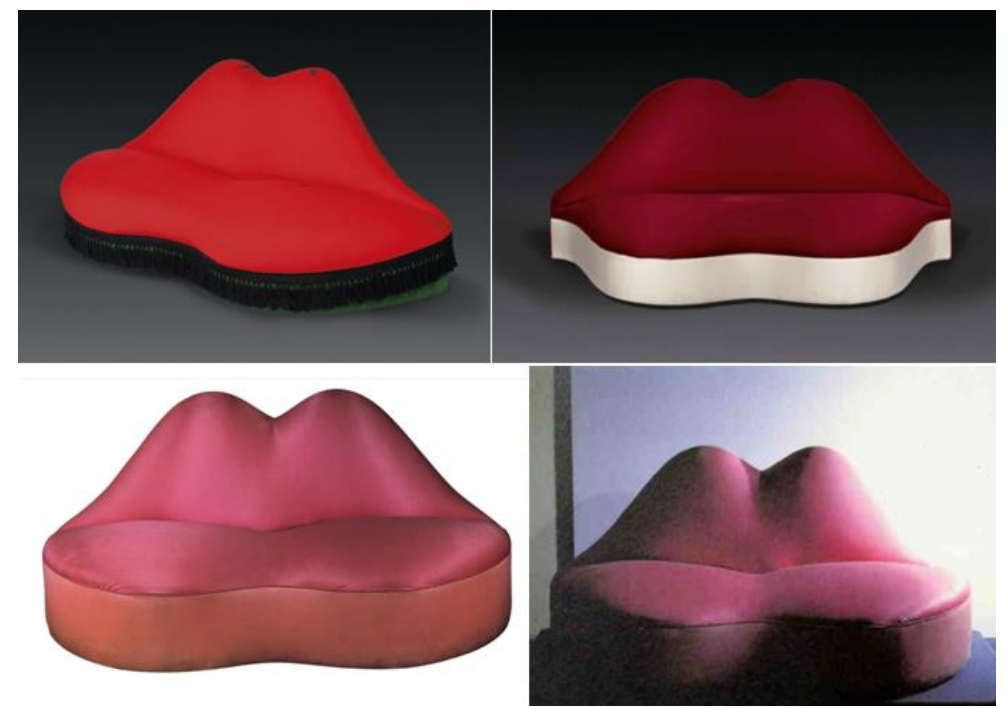

Resim 23. Dali'nin Meşhur Koltuğunun Versiyonları Sırasıyla; "Mae West Lips Sofa" 1936, 1936 Yılındaki Beyaz Kumaşlı Versiyonu, "Sofa in the Form of Mae West's Lips" 1938, "Mae West Lips Sofa" 1937 (URL-24).

Sigmund Freud bir keresinde bir odanın rüya görüntüsünün bir kadını temsil ettiği sonucuna vardı. Freud'un psikanalitik öğretileri, sürrealist düşüncenin gelişimi için anahtar kavramlardı. Dalí, geleneksel varoluş biçimlerinin manipülasyonu için ne kadar çabalasa da kadınsı güzellik modelinin 1920'lerin Hollywood film yıldızı ve seks sembolü Mae West olduğuna inanıyordu. Dalí, 1934'te, Mae West'in bir gazete

\footnotetext{
${ }^{6}$ Melton, orta gramajlı, tuşesi yumuşak ve sıcak yünlü kumaştır.
} 
fotoğrafını kullanarak yüzünü bir apartman dairesine dönüştürdüğü bir çalışma yaratmak için paranoyak sanatsal yöntemini aşıladı. Bu gerçekçi sahnede West'in yüz hatları mobilya ve süs motiflerine dönüşerek bir odanın sürrealist tasvirini yarattı. Yıllar sonra Dalí, bu kolajı sanatçının Mae West odası için ilham kaynağı olarak kullandı ve Katalan mimar ve tasarımcı Òscar Tusquets ile konsepti daha da geliştirdi. 1974'te Dalí ve Tusquets, sahneyi fiziksel bir alan olarak işlemek için işin tek tek öğelerini çıkarmaya başladı ve sanatçının mobilyalarla çevrelenmiş paradoksal, mekânsal görünüşü keşfetmesini ilerletti; West'in dudakları pembe bir aşk koltuğuna, burnu bir şömineye, gözlerini temsil eden soyut imgelere ve perde görevi görecek sarı bir peruğa dönüştürüldü (URL-25). Enstalasyondaki tartışmasız en tanınmış unsur olan odadaki dudaklı kanepenin şekli, sadece Mae West'in dudaklarından değil, aynı zamanda Gaudi mimarisinin gösterişli, kabaran kıvrımlarından da türetilmiştir (Resim-24).

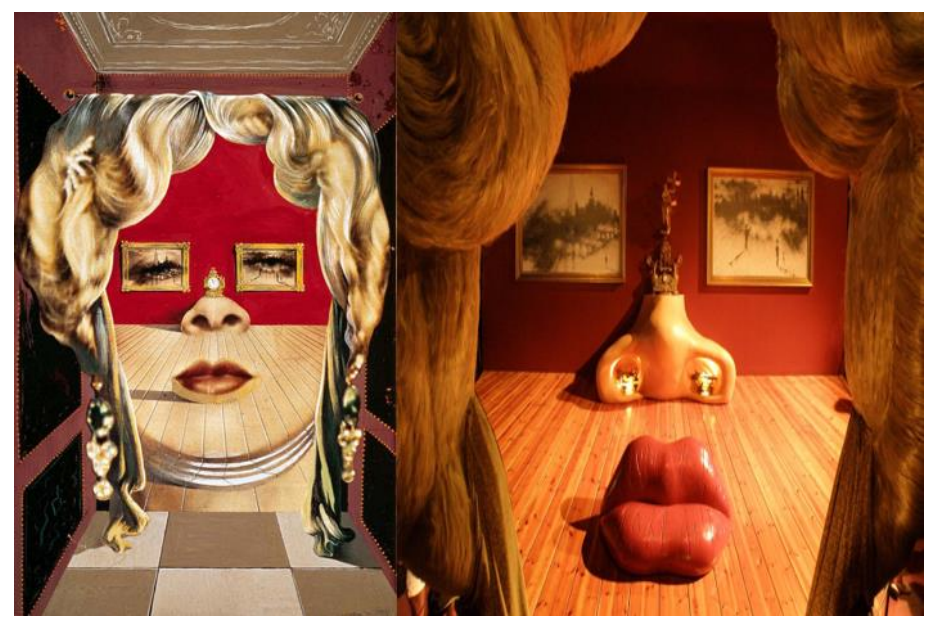

Resim 24. Mae West Room Tablosu (1934), Resimden Tasarlanan Oda (1974-1975) (URL-25).

"Tumbona Portlligat" Dalí'nin evinin bahçesi için tasarladığı veya yeniden yorumladığı en kişisel mobilya tasarımıdır. Portlligat şezlongunun (1962) başı, gövdesi, kaburgaları, kolları, elleri, bacakları ve ayakları vardır. İroko ağacından iskelet strüktür olarak yapılmıştır. Su tutmayan tekstil kaplı ve köpük poliüretan dolgulu minderi ile dış mekân kullanımı için tasarlanmıştır ( Resim-25).

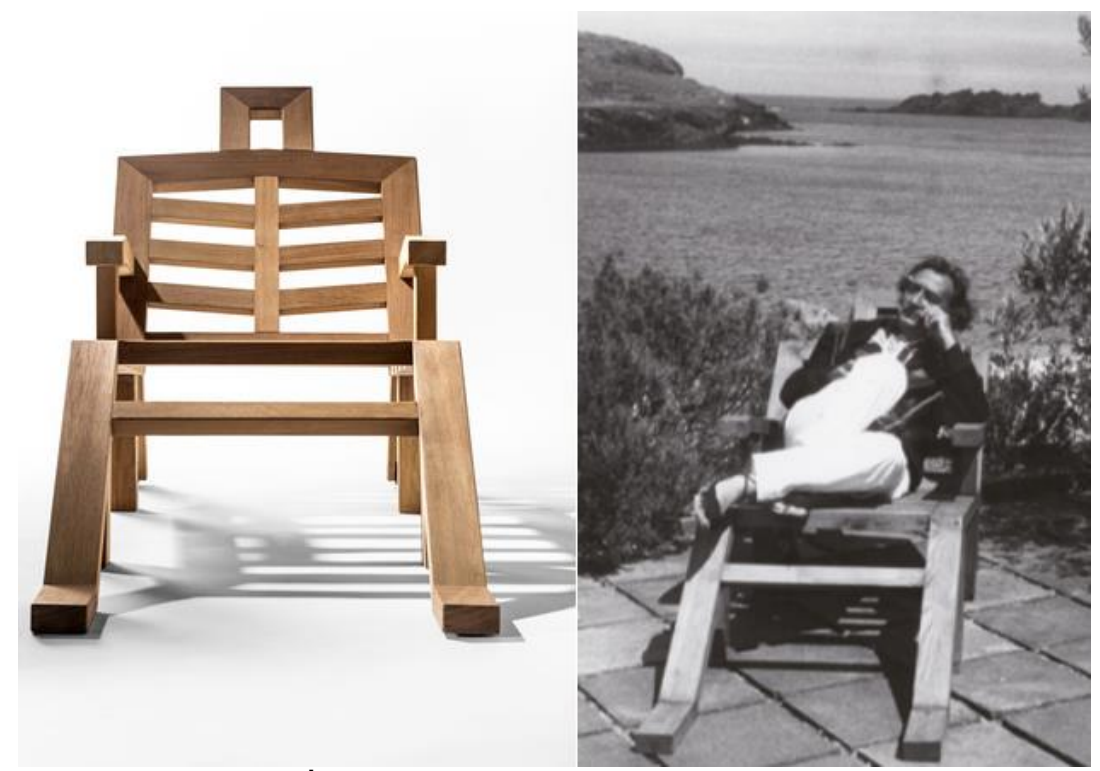

Resim 25. "Tumbona Portlligat" İsimli Şezlong (1962) ve Dali Şezlongunda Otururken (URL-22). 
"Vis-à-vis de Gala" isimli kanepe Dali'nin 1935-1937 yılları arasında tasarladığı aşırı burjuva ve geleneksel bir mobilya parçasının tipik sürrealist yorumudur. Bu mobilyada kanepede oturanları kucaklayan mücevherli bir kadın eli ve saatli bir erkek eli bulunmaktadır. Masif ahşap konstrüksiyonun tamamlayıcısı olarak konik yaylar ve kıskaçlarla geleneksel bir döşeme yapılmıştır. Döşemenin içindeki beyaz pamuklu iç astarın üzeri parma menekşe renginde doğal ipek döşemelik kumaş ile kaplanmıştır. Kanepenin süsleme kısımlarında pirinç malzeme kullanılmıştır. El üzerinde imitasyon yakut kullanılmıştır (Resim-26).

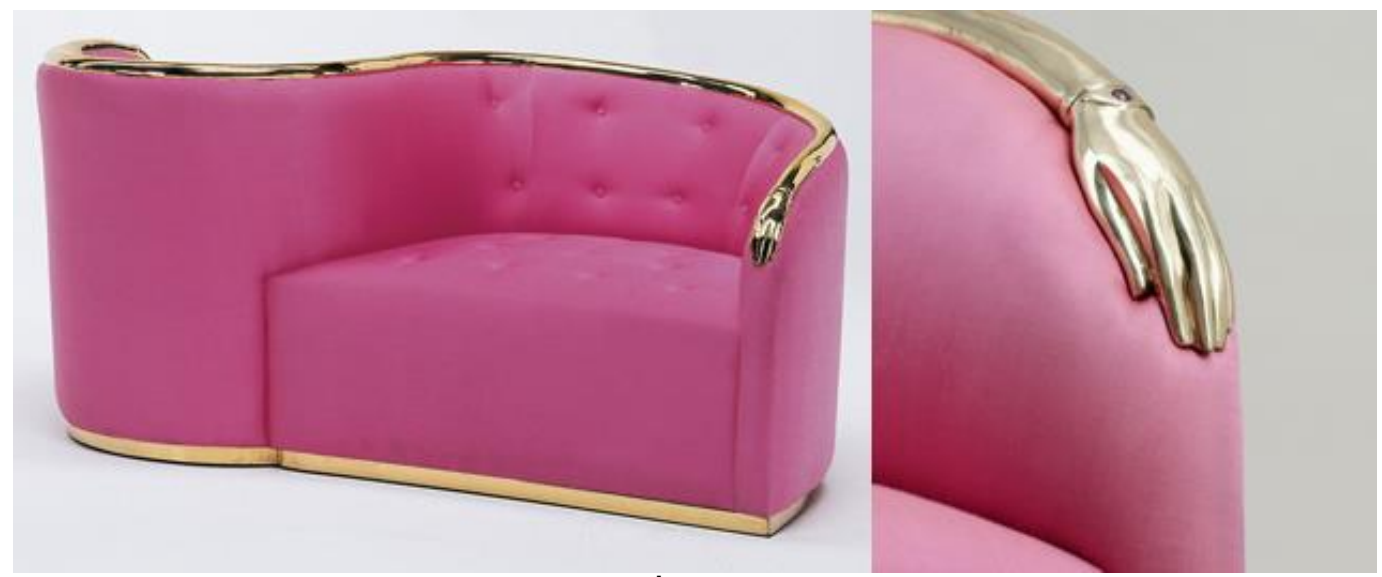

Resim 26. “Vis-à-vis de Gala” İsimli Kanepe 1935-1937 (URL-22).

Az bilinen bir mobilya çalışması "Side Table with Six Tiles" isimli demir konstrüksiyon üzerinde seramik tablalı dekoratif sehpadır. Sehpa Tablası olarak kullanılan 20x20 cm ölçülerinde 6 adet seramik de Dali'nin kendi tasarımıdır. Dali'nin metal ve seramik kullanarak tasarladığı bir başka sehpada ayakların sehpanın kenarlarında dönerken taşıma için kolaylık sağlayan tutamaçlar oluşturduğu ve altta bir ızgara raf bulunduğu görülmektedir (18 x 25,25 x 17,25 cm) (Resim-27).
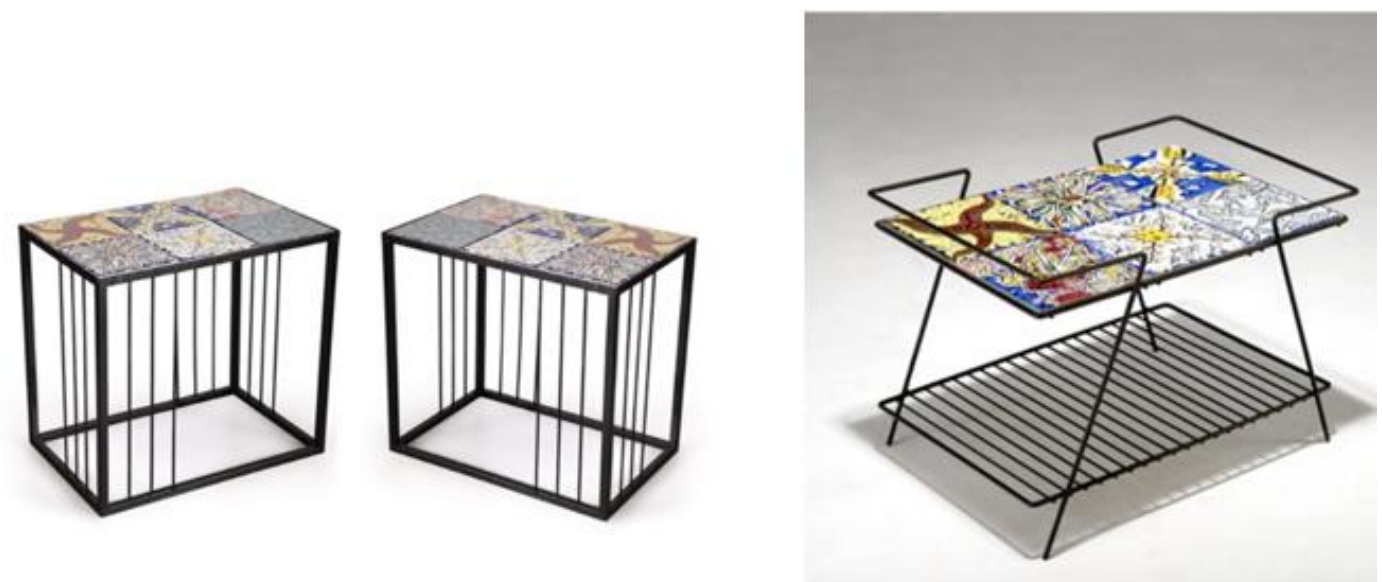

Resim 27. Dali'nin Tasarladığı Seramik Tablalı Sehpalar (URL-21)

Birçok tasarımcı ve firma tarafından benzeri ve türevleri üretilen bir mobilya da 1980 yılı yapımı saatli iskemlelerdir ( $85 \times 41 \times 44 \mathrm{~cm}$ ). Giriş bölümünde de belirtildiği üzere saat Dali'ye çocukluğunu ve babasını hatırlatan bir nesne idi. Birçok eserinde saat imgesini kullanan sanatçı bu iskemlenin sırtlık kısmında saati kullanmıştır. Metalik lake boyalı ahşap konstrüksiyon iskemle döşemesinde sentetik deri malzeme ve döşeme süngeri kullanılmıştır (Resim-28). 


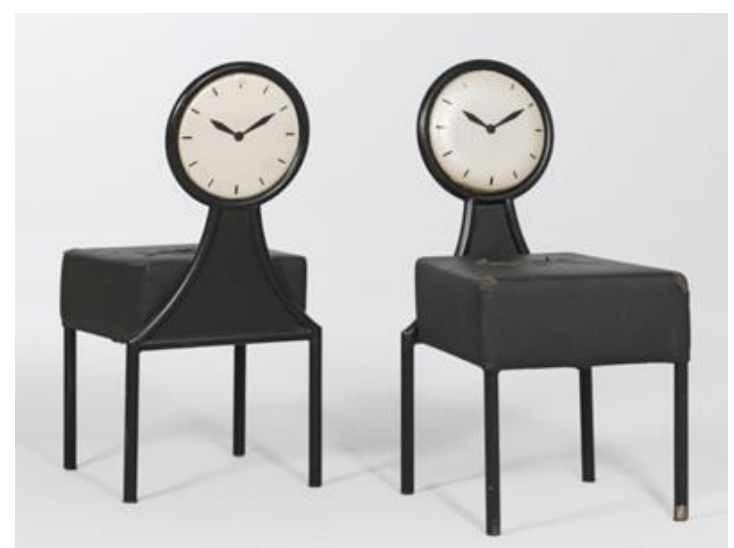

Resim 28. 1980 Yılı Tasarımı İskemleler (URL-26).

Dali'nin tasarladığı mobilyalar arasında aydınlatma elemanları da bulunmaktadır. 1937 yılında tasarladığı üç lamba bu konudaki önemli örneklerdir. "Cajones Lamba" mat vernikli limon ağacından oyma ile şekillendirilmiş; üzerinde çelik iskeletli bej rengi ketenden abajuru olan ve iç mekânda kullanılmak üzere tasarlanmış bir aydınlatma elemanıdır. 300 × $300 \times 870$ mm- $120 \times 120$ × 340 mm ölçülerindeki lambanın üzerinde beş adet farklı büyüklüklerde çekmeceler bulunması ve lambanın orta kısmında iki dal parçasının birleşmesi önemli özellikleridir. "Bracelli Lamba" gümüş kaplama polyester boya ile kaplanmış panel yapıya sahiptir. Üzerinde fildişi renginde ve suni ipekten bir abajur bulunmaktadır. 370x 640 × 1800 mm- 145 x 250 x 710 mm ölçülerindeki zikzak şeklindeki lambanın arkasında Cajones Lambanın gövdesindeki dal formu ile yapılmış bir destek bulunmaktadır. "Muletas Lamba" Cajones Lamba ile aynı malzeme ve yapım tekniği kullanılarak yapılmıştır. Aynı dal formu bu lambada beş kez tekrarlayarak kullanılmıştır. 450 × 450x 1870 mm- 180 x 180 x 740 mm ölçülerindeki lamba birbiri ile bağdaşan beş ayrı parçanın oluşturduğu bir gövdeden oluşmaktadır (Resim-29).

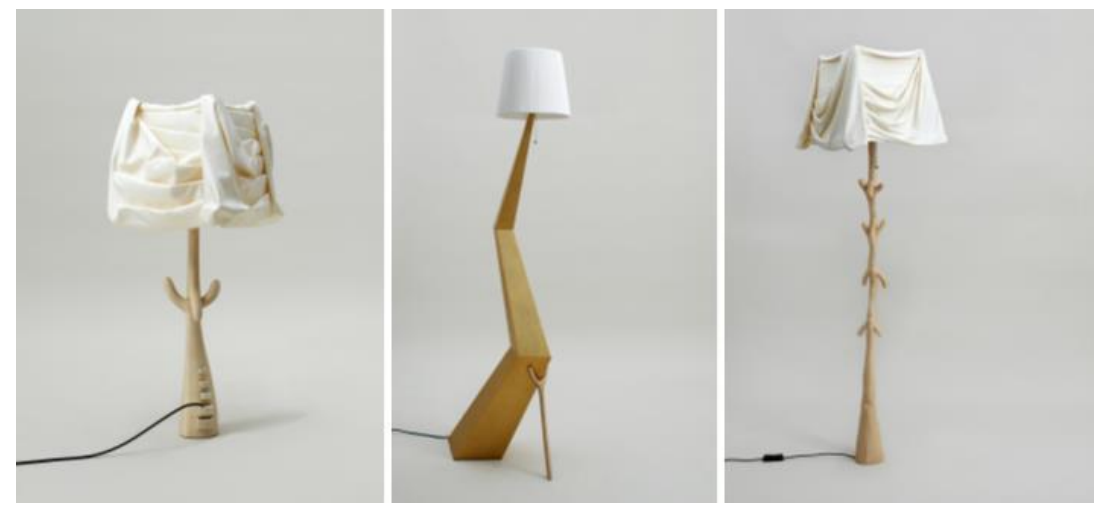

Resim 29. Sırasıyla "cajones Lamba”, "Bracelli Lamba” ve "Muletas Lamba” (1937) (URL-22).

"Venus de Milo with The Drawers/ Çekmeceli Venüs" (1936) bir özel koleksiyon eseridir. Bu eseri asistanı Marcel Duchamp ile birlikte yapmıştır. Alçı döküm tekniği ile yapılan heykelin diz, karın ve göğüs kısmına ahşap çekmeceler yerleştirmiştir (Resim28). Çekmeceler ve çekmece içindeki bölüntüler bilinçaltındaki bölümleri ifade etmektedir. 1964'de bu eserini bronz döküm olarak yeniden yapmıştır. Esasen Dali antik döneme ait Venüs heykelini çekmeceler ve çekmece kulplarına yapıştırdığı pelüşlerle değersiz ve gereksiz bulduğunu ifade etmek için yeniden yorumlamıştır (URL-27). Bu çekmeceleri Sigmund Freud, bir ceza olarak değerlendirmiş ve tutamak yerine de ponponlar yerleştirmesini erotik bir anlatım olarak değerlendirmiştir (Üstel Arı, 2019, s.321-330). Eser, aşk ve güzellik tanrıçası Venüs'ün henüz irdelenmeye 
başlanılan bilinçaltındaki gizlenmiş cinsel arzular ve psikolojik gizemlerin, sürrealizmle çarpıtılmış bir versiyonu olarak görülebilir. Benzer bir mobilyayı " Antropomorphic Cabinet" (1936) isimli eserinde ve "The Burning Giraffe / Yanan Zürafa" (1936-37) eserinde görmek mümkündür. Dali bu eserinin çeşitli ölçü ve malzemeler ile versiyonlarını yapmıştır (Resim-30, 31).
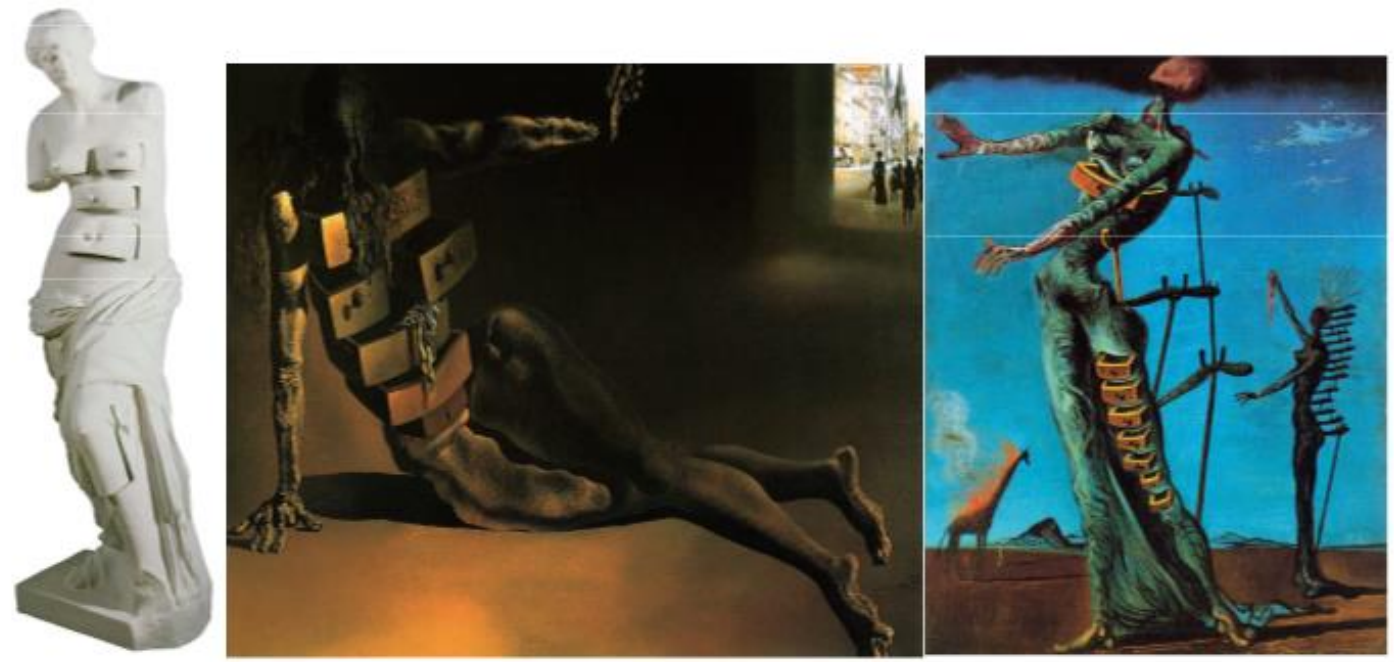

Resim 30. "Venus de Milo with The Drawers/ Çekmeceli Venüs" (1936), "Antropomorphic Cabinet" (1936) ve "The Burning Giraffe / Yanan Zürafa" (1936-37) eserleri.
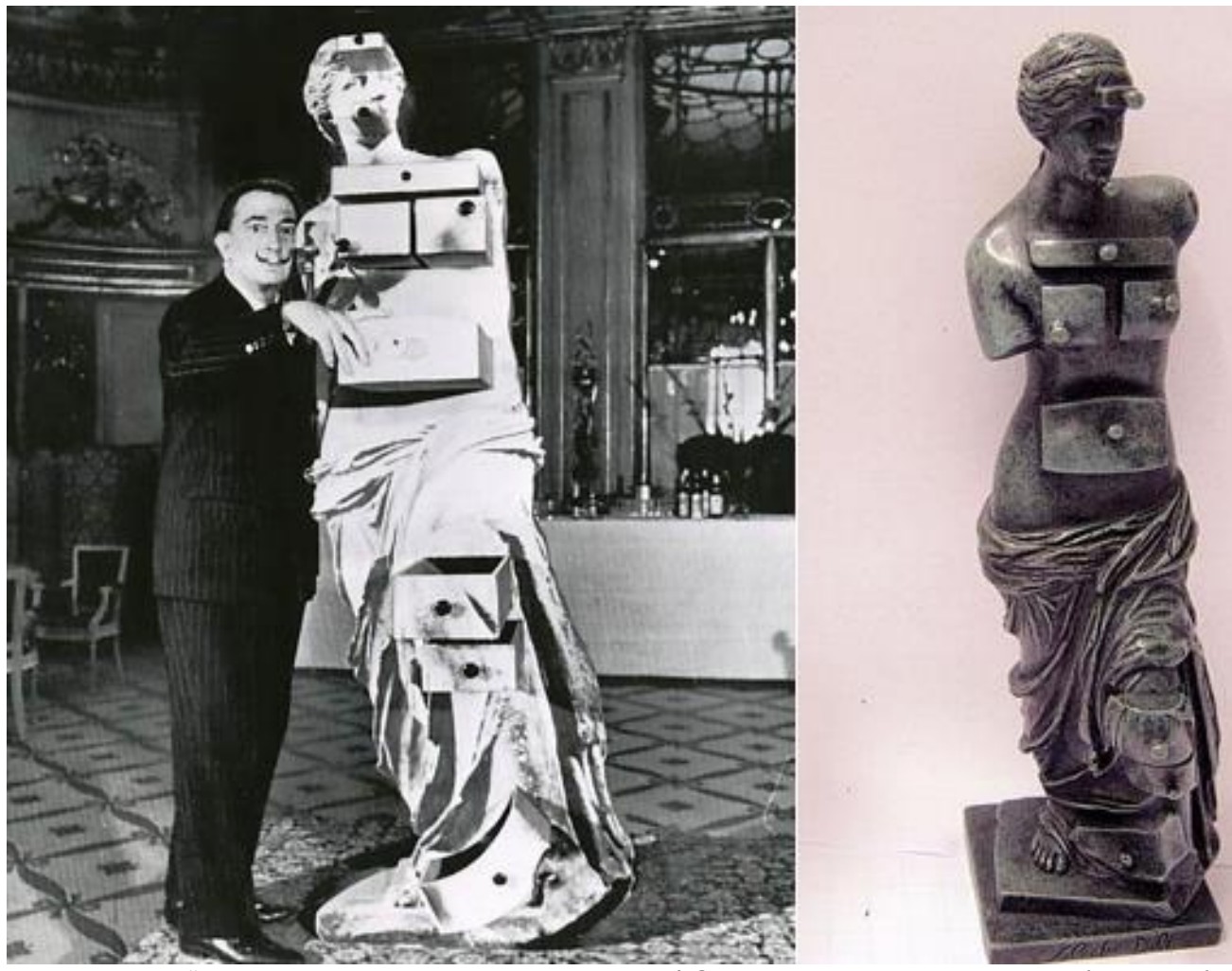

Resim 31. "Venus de Milo with The Drawers/ Çekmeceli Venüs" ve Dali (URL-28) (URL-29). 


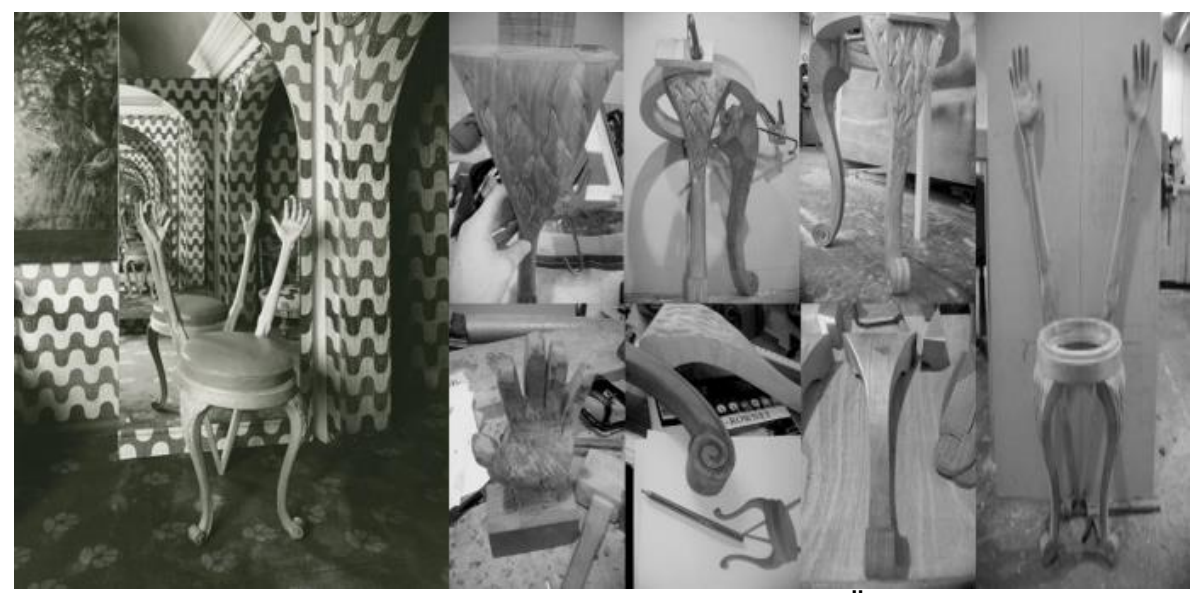

Resim 32. "Hands Chair" )1938, Monkton Evi (URL-34) ve Üretim Detayları (URL-31).

"Hands chair" 1938 yılında sanatçının arkadaşı Edward James'in Monkton Evi için tasarladığı bir iskemledir. Bazı kaynaklarda 1936 yılı yapımı olduğu yazmaktadır (URL32). Günümüzde bu sandalyenin üretimi devam etmektedir. Oymalı ceviz çerçeve konstrüksiyon üzeri mor deri kaplı oturma fontundan oluşmaktadır (Resim-32) (URL33). Monkton Evi'nin salonunda yer alan "“Mae West Lips Sofa" ve "Champagne standard lamps/ Şampanya Standart Lambaları" (1938) James ve Dali'nin tasarlayarak ürettiği diğer mobilyalardır (Resim-33).

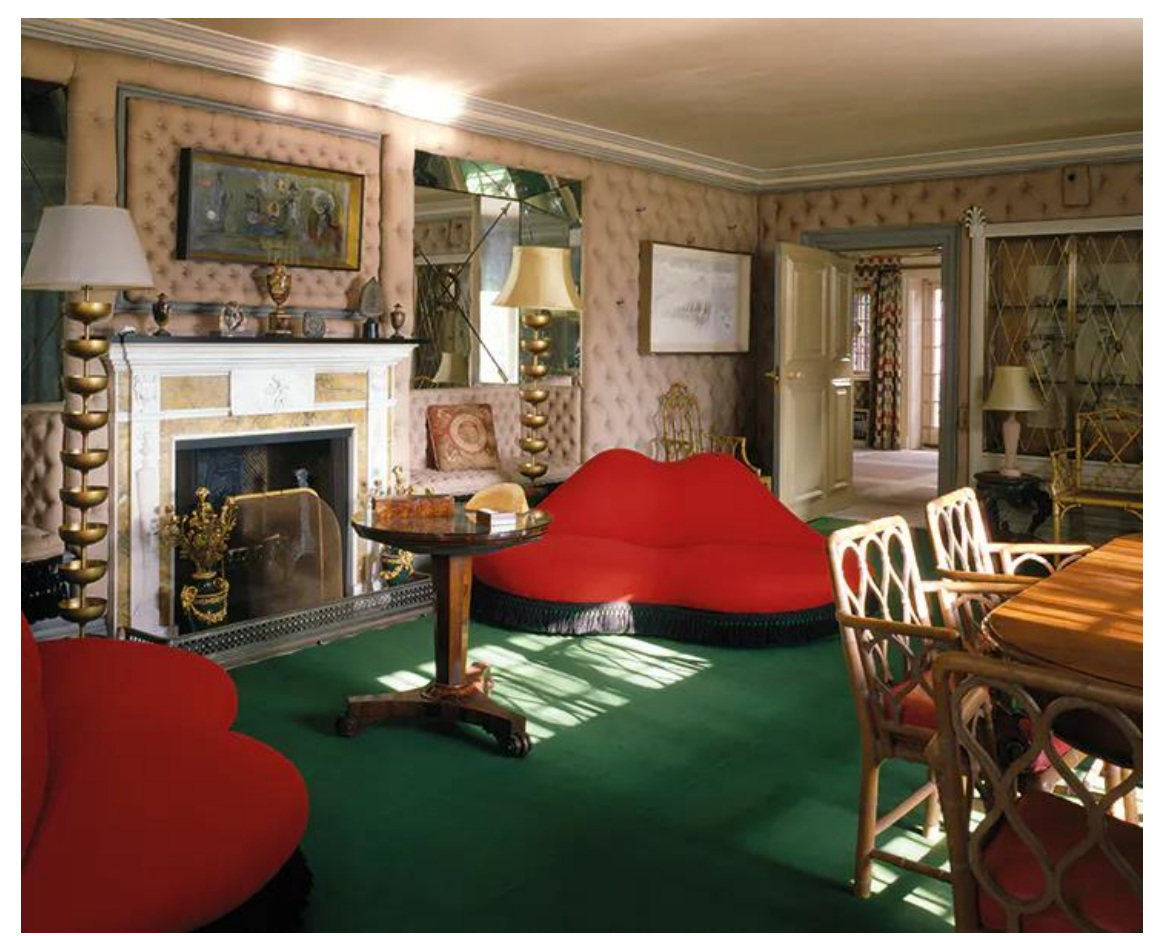

Resim 33. Monkton Evinde Edward James ile Birlikte Yaptıkları Koltuk ve Lamba Tasarımları (URL-34).

Dali filmler ve sahne gösterileri için yaptığı dekorlara özel mobilyalar da tasarlamıştır. Marx Kardeşler için yapılan bir dekorda ise, kırmızı kapitoneli bir kadınlık organının çevresine yerleştirilmiş el biçimindeki duvar şamdanları oraya doğru yaklaşan kişinin üstüne doğru kapanır. Dali, ünlü yönetmen Alfred Hichcock'un yönettiği Doktor Edwards'ın Evi filmindeki kumar masalarını da tasarlamıştır. Kumar masasının bacakları kadın bacağı şeklindedir ve dengesiz bir göz piyano ortalıkta sallanır. Burada 
cinsel bir nitelik verilmiş, hareketli sapkın Dali eşyaları bir yandan anlam belirsizliğini artıracak şekilde modern stilin kıvrımları ile kaplıdır (Resim-34).

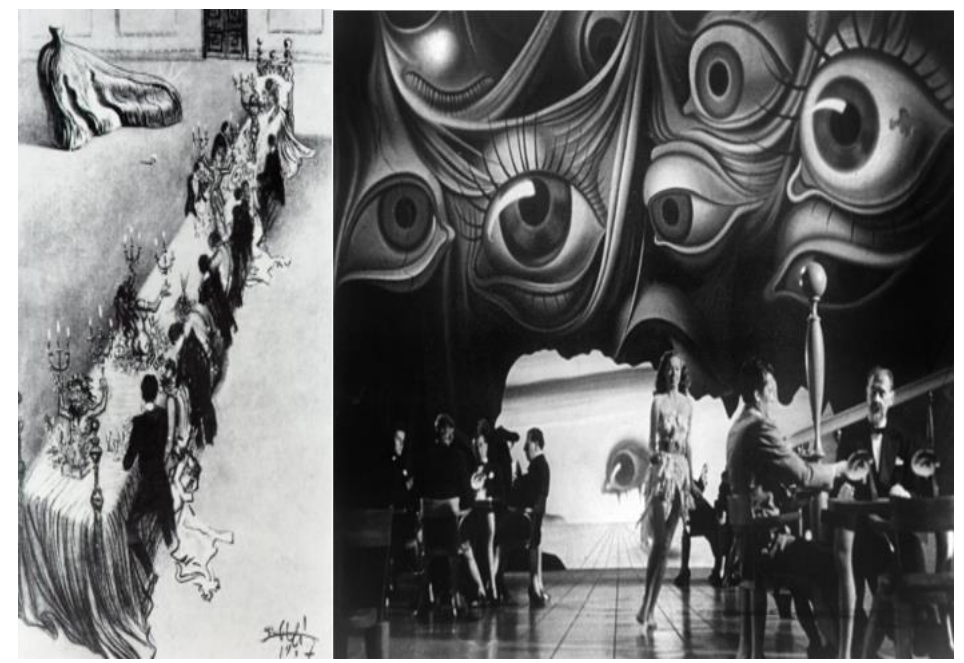

Resim 34. "Yatağın Üzerinde Sürrealist Yemek Sofrası” (1937) Marx Brothers'ların bir Filmi İçin Dekor Çizimi (URL-35) ve Doktor Edwards'ın Evi Filminde Dali Tarafından Tasarlanan Kumar Masası ve Dekor (1:26.00) (URL-36).

\subsection{Dali'nin Eserlerinden Yararlanılarak Tasarlanan Mobilyalar}

Dali'nin mobilyayı kompozisyonlarına kattığı, bir imge olarak kullandığı çok sayıda eskiz, illüstrasyon, tablo, heykel çalışması ve bizzat yapmış olduğu mobilya tasarımları yanı sıra eserlerinde resmedilmiş ilginç sürrealist mobilyaların başka tasarımcılar tarafından bir mobilya haline dönüştürüldüğü örnekler mevcuttur. Bu tasarımcılar Dali'nin tablolarında yer alan mobilya imgelerini üç boyutlu bir mobilya haline dönüştürmek üzere konstrüksiyon, malzeme, ölçü ve işlev açısından yeniden ele alarak tasarlamışlardır.

"Personaje Invisible/ Görünmez Şahsiyet" isimli koltuk Dali'nin 1935 yılında "Singularidades" adlı eserinden esinlenerek tasarlanmıştır. Aynı koltuk Dali'nin bir başka tablosunda daha görülmektedir. Tasarlanan koltuk sanatçının arkadaşı Oscar Tusquets'in 1972 yılında başlatmış olduğu Dali mobilya koleksiyonu için oluşturulan bir mobilyadır. Koyun postu ile kaplanmış kompozit strüktürden oluşan koltuğun üst kısmında poliamid laklı şarj edilebilir LED lamba bulunmaktadır (Resim-35,36).
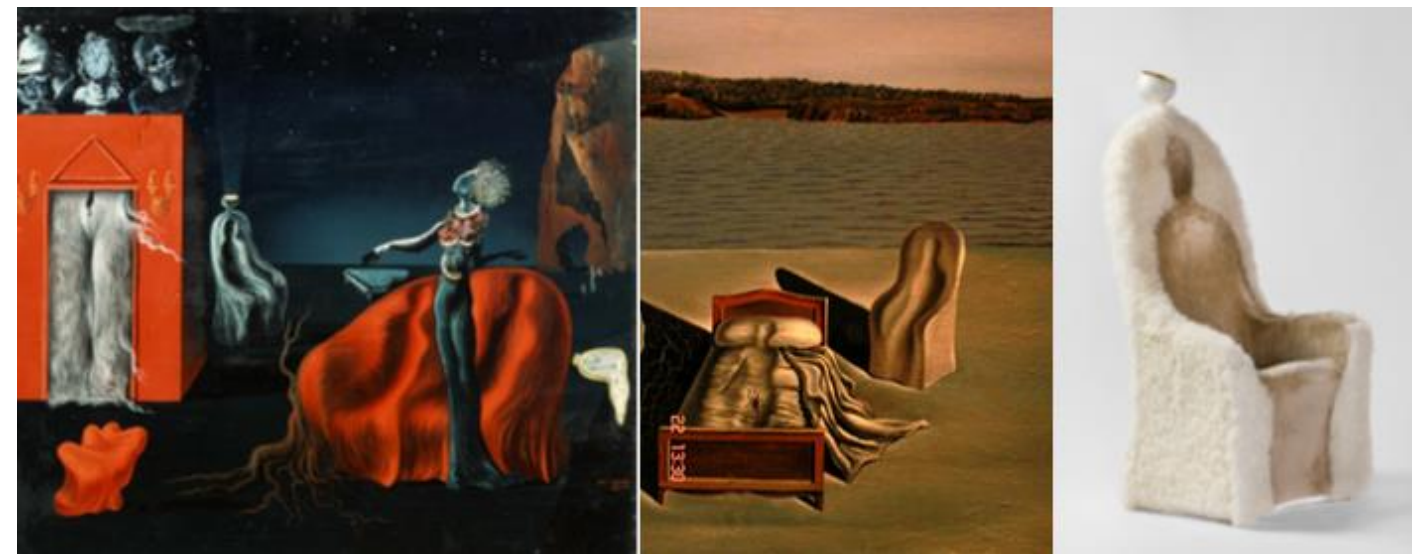

Resim 35. "Singularidades" (1935) İsimli Tablo ve Dali'nin Bir Başka Tablo Çalışmasında "Görünmeyen Figürlü Sürrealist Kompozisyon" (Demirarslan, 2008) “Personaje Invisible” İsimli Koltuk ve Bu Koltuğun Üretilmiş Hali (URL-37). 


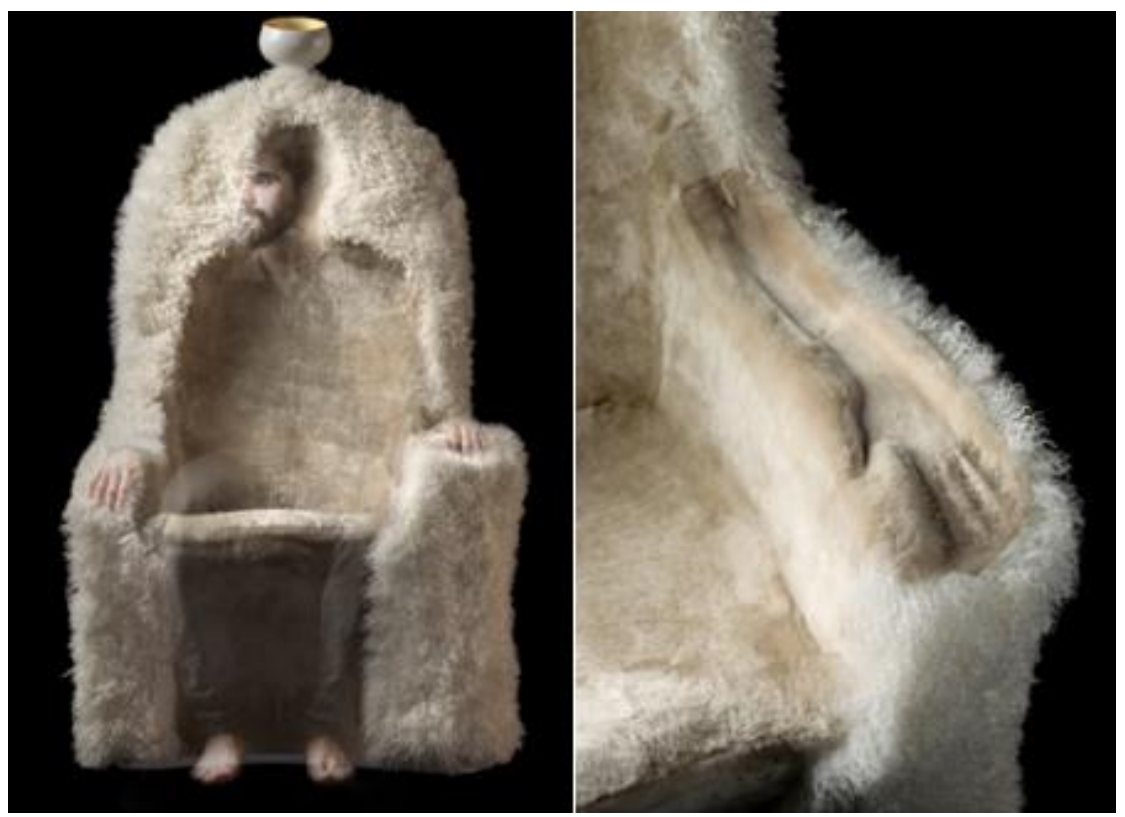

Resim 36. "Personaje Invisible/ Görünmez Şahsiyet” İsimli Koltuktan Detaylar (URL-37).

"XAl" isimli mobilya, sanatçının "Proyecto de interpretación para un establo-biblioteca" (1942) isimli yapıtından esinlenerek tasarlanmıştır. Masif vernikli ceviz ağacından çekmece ve masa tablası, yaldızlı masif bronz toynaklardan oluşan mobilyanın yüzeyi gerçek koyun postu ile kaplanmıştır. Ancak bu iş için özel olarak hayvan kesimi yapılmamış; mezbahadan alınan postlar kullanılmıştır (Resim-37).
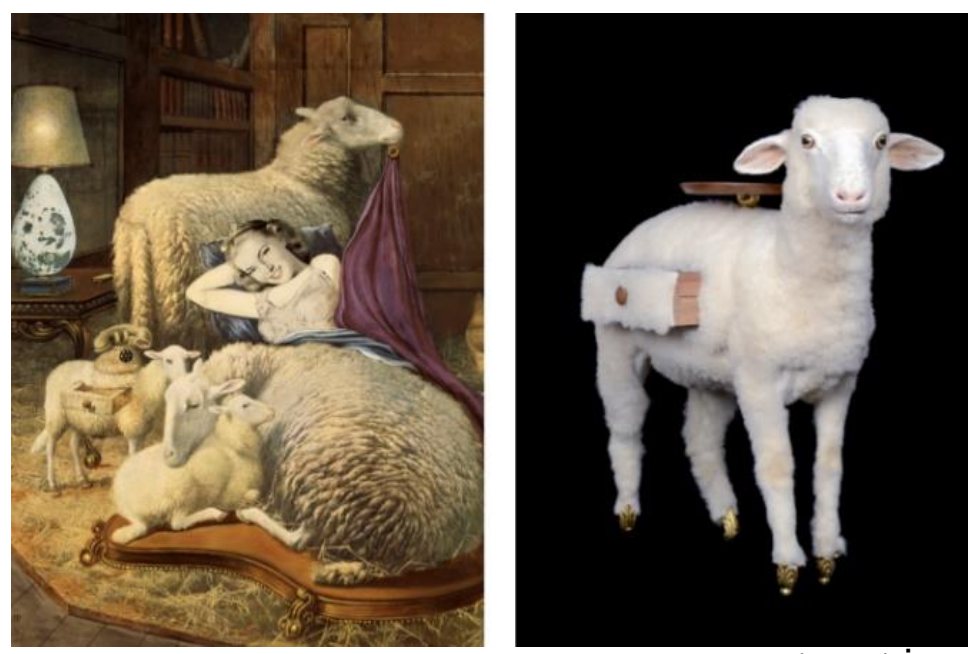

Resim 37. "Proyecto de Interpretación Para un Establo-Biblioteca" (1942) İsimli Tablo ve "XAl" Mobilya (URL-37).

"Sillón-Escultura Leda" sanatçının 1935 yılında yaptığı "Femme à tête de roses/ /Gül Başlı Kadın" isimli resmindeki iskemleden esinlenerek üretilmiştir. "Femme à tête de roses" resminden alıntı yapıldığında, sadık bir Dalí parçası elde etmek için resmin detayını üç boyuta koymak yeterli olmuştur. Dalí bu resimdeki iskemle için şöyle demiştir: "Oturmak için bir sandalye bile kullanılabilir, ancak sadece bir şartla: kötü oturalım." Leda'nın üzerine oturabiliriz, ancak sadece üç ayağı olması ve sağlam pirinç malzemeden verdiği görsel ağırlık, onu işlevsel bir parçadan çok bir sanat eseri haline getiriyor." Bu iskemle, kayıp balmumu döküm yöntemi ile pirinç malzeme kullanılarak çeşitli parçalardan yapılmıştır. Parçalar birbirine kaynaklanmıştır (Resim-38). 

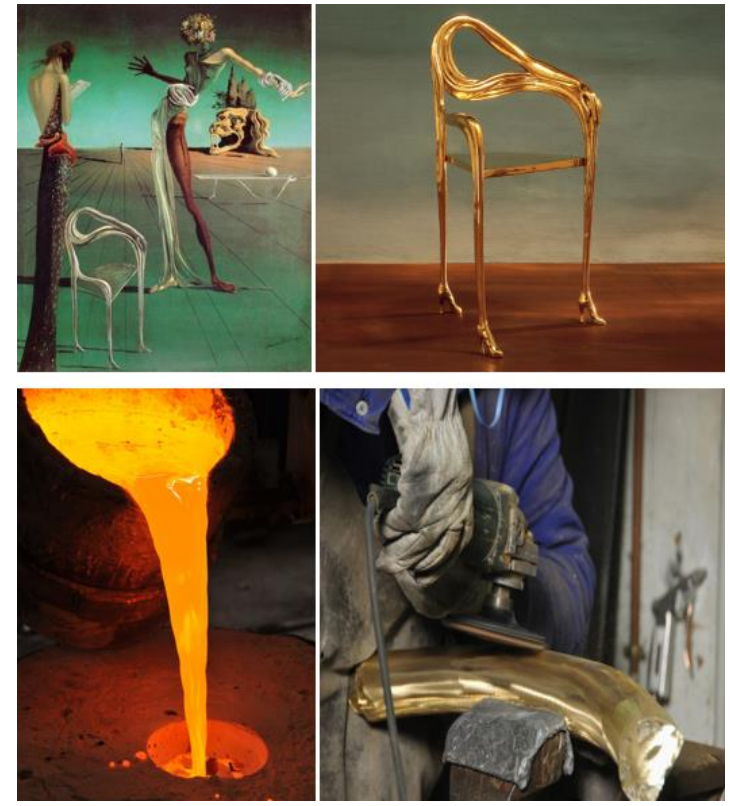

Resim 38. "Femme à Tête de Roses /Gül Başlı Kadın " Tablosu, "Sillón-Escultura Leda" İskemle ve Yapım Detayları (URL-37).

"Mesa Baja-Escultura Leda" isimli masa da yine sanatçının 1935 yılında yaptığı "Femme à tête de roses" isimli resmindeki sehpadan esinlenerek üretilmiştir. Tablodaki sehpaya sadık kalmak üzere pirinç ve mermerle yorumlanmıştır. Sehpa biçimi ve yapısı gereği ev içi kullanım için uygun olup; kamusal alanlarda kullanımı uygun değildir. Leda iskemlesinde olduğu gibi, Dali, bacakların şekline gerçeküstü bir çözüm olarak vücudun kısımlarını (kollar ve bacaklar) kullanmıştır. Dalí'nin çok sevdiği sembolik unsurlardan biri olan yumurta figürü de sehpanın üzerinde ortaya çıkmaktadır (Resim-39).

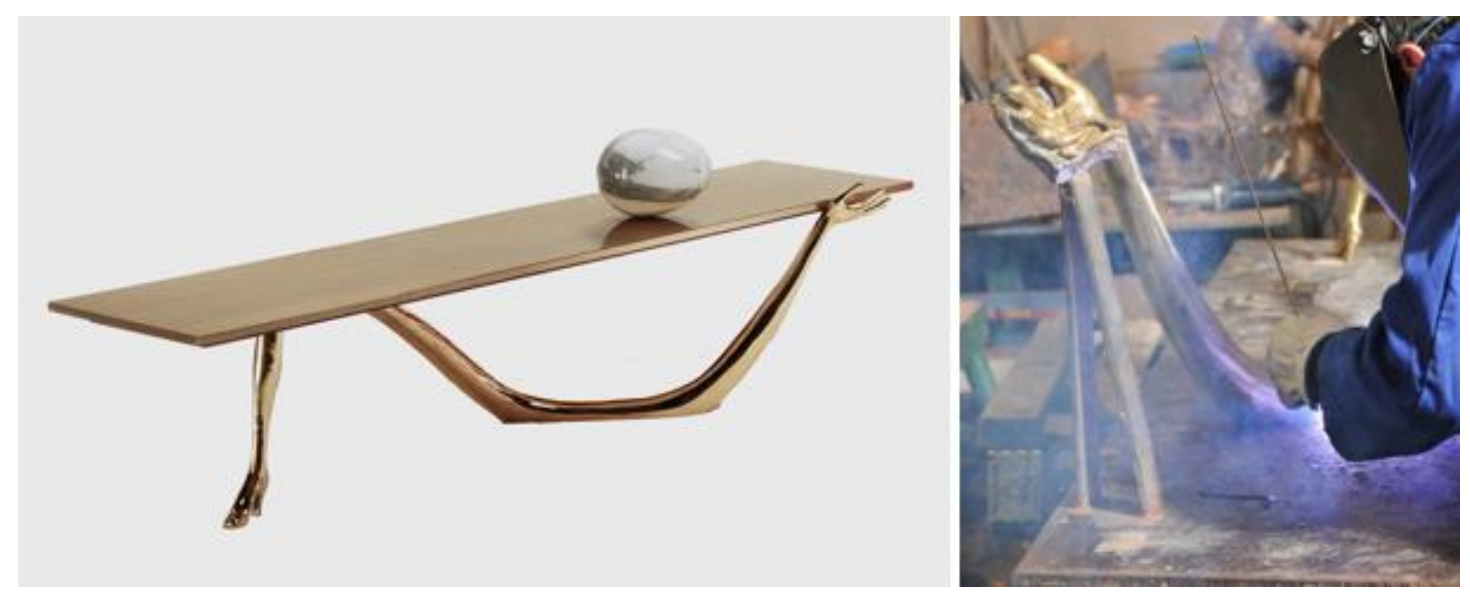

Resim 39. "Mesa Baja-Escultura Leda” ve Yapım Detayı (URL-37).

\section{Bulgular}

İnceleme sonucunda Dali'nin mobilya ile ilişkisi şöyle gruplanabilmektedir:

-Kendi evi için tasarladığı ve kullandığı mobilyalar: Kendi evi için Orta Doğu-Arap kültüründen esinlenerek tasarladığı yapıya bağlı mobilyalar ile oturma ve yemek odaları ve bahçe düzenini oluştururken, evin hemen her mekânında resimlerinde sıklıkla kullandığı iskemleleri gerek oturmak gerekse de dekoratif amaçlı kullanmıştır. Bu mobilyaları da mobilya yapımı ile ünlü Olot kasabasından almıştır. Hareketli oturma mobilyalarında Barok, sabit mobilyalarda Doğu esintileri görülmekle birlikte Kitsch 
sanatı özellikleri taşıyan mobilyalar yaparak kullanmıştır. Satın alınmış mobilya ve nesnelere kendi dokunuşları ile yorum katmış ya da bir dekor gibi oluşturduğu iç mekânın bir parçası haline dönüştürmüştür.

-Eserlerinde imge olarak kullanım: Sanat yıllarının başından itibaren birçok sanat yapıtında mobilyayı imge olarak kullanmıştır. Bazen çocukluk hatıraları, bazen cinsellik ile ilgili bir mesaj olarak yapıtlarında yer almıştır. Benzer şekilde diğer sürrealist sanatçıların resimlerinde mobilyayı imge olarak görmek mümkündür. İmge olarak kullanımda çekmece, iskemle, masa ve koltuk en önemli mobilyalardır.

- Tasarlamış olduğu ve üretilerek satışa sunulan mobilyalar: Bizzat tasarlamış olduğu mobilyaları bir tablo şeklinde özetlenmiştir (Tablo-1). Bu mobilyalar halen daha üretilmekte ve satılmaktadır.

- Eserlerindeki mobilyaların diğer tasarımcılar tarafından üretildiği mobilyalar: Eserlerinde yer alan mobilyaların diğer tasarımcılar tarafından üretilenleri bir tabloda özetlenmiştir (Tablo-1). Bu mobilyalar halen üretilmekte ve satılmaktadır.

- Film Dekorları ve iç mekân dekorasyonları için tasarladığı mobilyalar şeklinde gruplanabilmektedir.

Tablo 1. Salvador Dali ve Mobilya Tasarımı ( URL-21, 22, 24,26 'daki bilgiler temel alınarak yazarlar tarafından hazırlanmıştır)

\section{SALVADOR DALI TASARIMI ve ÜRETILEREK SATIŞA SUNULAN MOBİLYALAR}

\begin{tabular}{|c|c|c|}
\hline $\begin{array}{c}\text { TASARIMIN } \\
\text { ADI }\end{array}$ & ÖZELLİKLER & TEKNiK Çizì \\
\hline 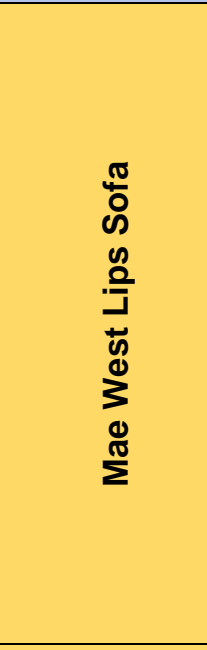 & $\begin{array}{c}\text { Tasarım Yılı: 1936, 1937,1938 } \\
\text { İlk koltuk Edward James ile } \\
\text { birlikte } 1936 \text { yılında } \\
\text { tasarlanmıştır. } \\
\text { Ölçüler: Versiyonlara göre } \\
\text { koltuğun ölçüleri } \\
\text { değişmektedir. İlk yapılan } \\
\text { koltuğun ölçüsü } \\
770 \text { x } 2050.7 \text { x } 960 \text { mm'dir. } \\
\text { Malzeme ve Yapım Yöntemi: } \\
\text { Koltuğun iç konstrüksiyonu } \\
\text { ahşap karkas olup; döşemelik } \\
\text { malzeme ve kaplama } \\
\text { versiyonlara göre saten, yünlü } \\
\text { kumaş, keçe vb. } \\
\text { değişmektedir. }\end{array}$ & \\
\hline 电 & $\begin{array}{c}\text { Tasarım Yılı: } 1972 \\
\text { Ölçüler: } 1700 \times 1000 x \mathrm{H} . \\
\text { 730mm (Font: H.370mm)/32kg } \\
\text { Malzeme ve Yapım Yöntemi: } \\
\text { Rotasyonel Kalıplama ve } \\
\text { Polietilenden üretilmiştir. }\end{array}$ & \\
\hline
\end{tabular}




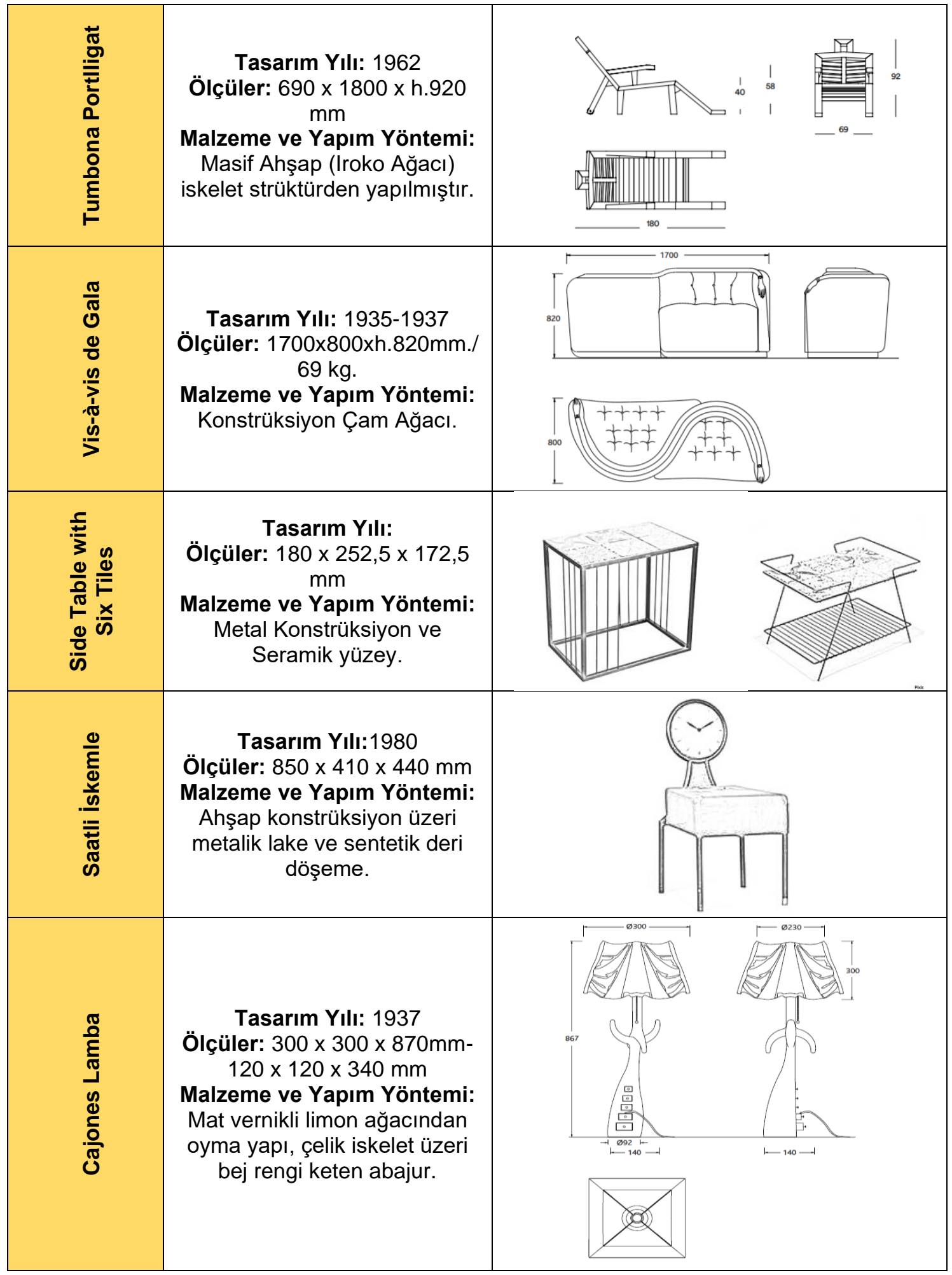




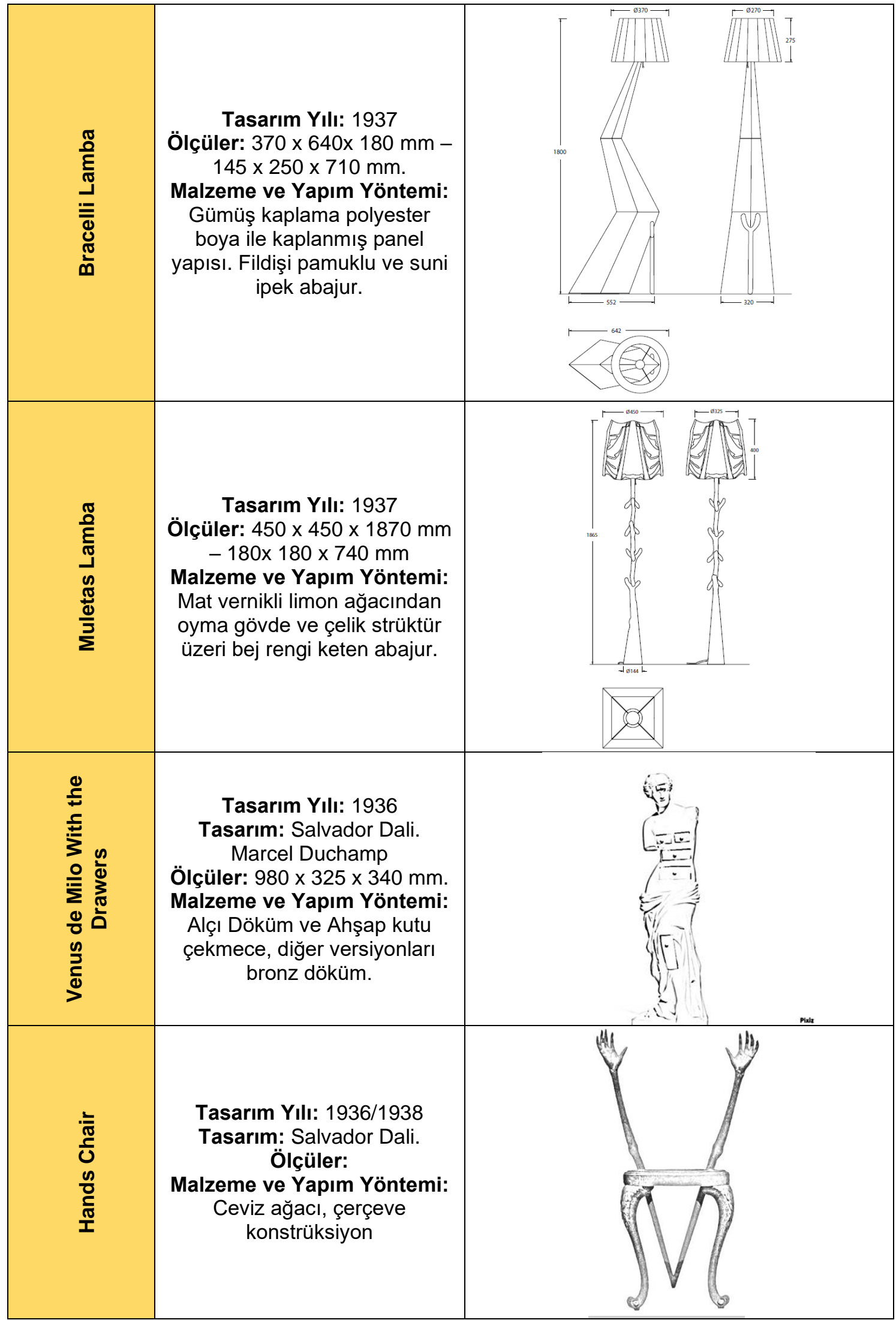




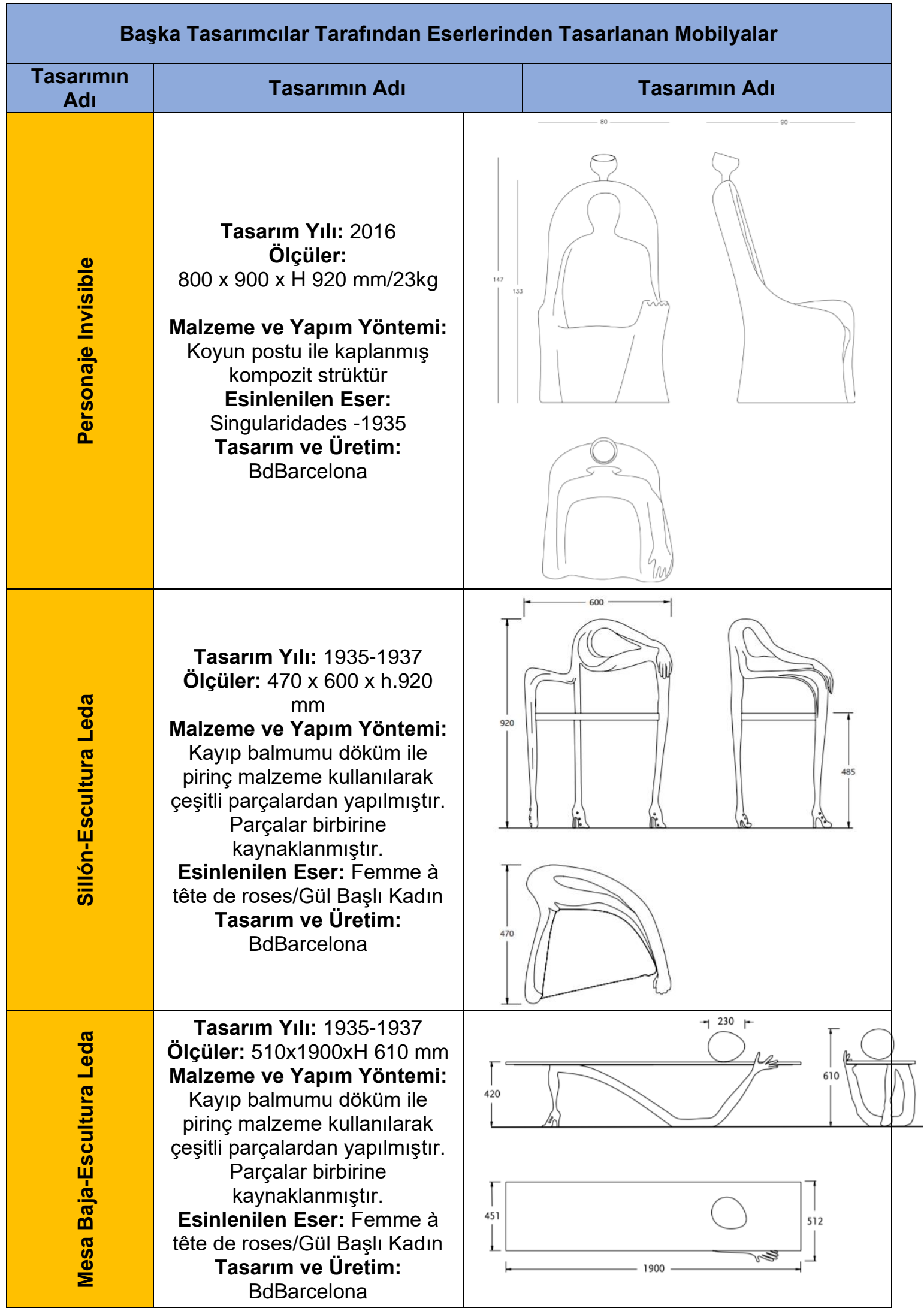




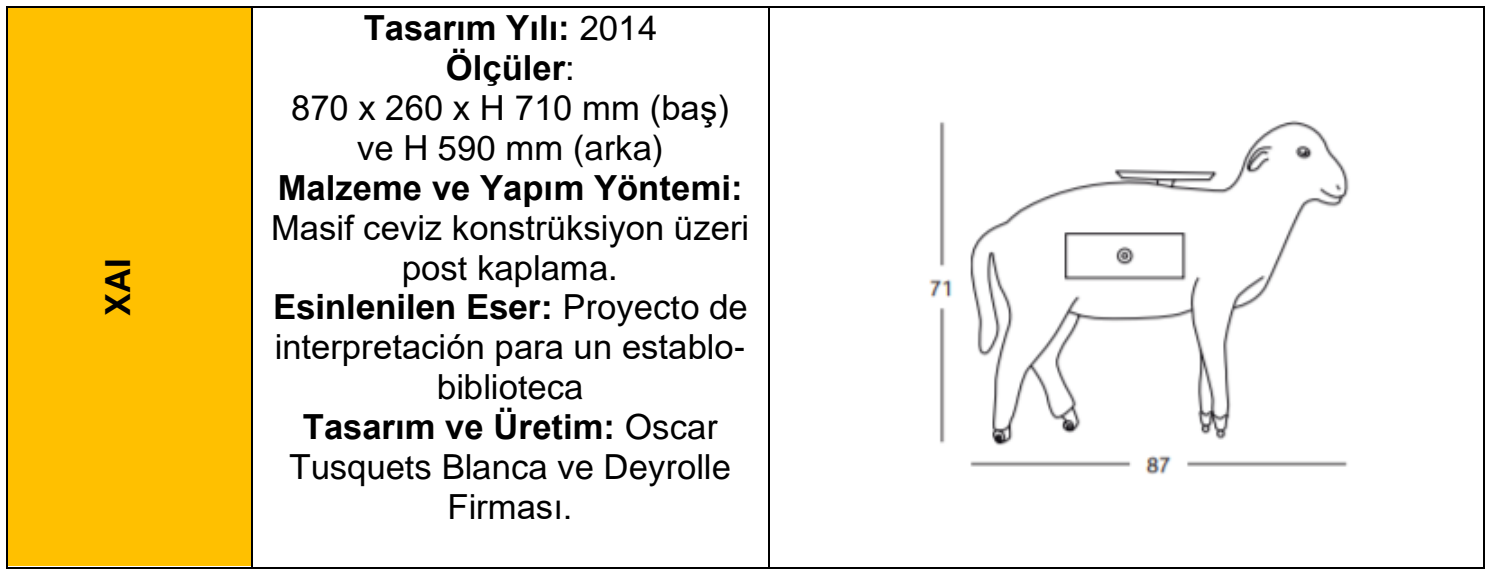

\section{Sonuç}

"Her sabah uyandığımda Salvador Dali olmanın Eşsiz keyfini yeniden yaşıyorum" Salvador Dali

"Amacım, hayal dünyasına gündelik dünya ile aynı derecede nesnellik ve gerçekliği vermektir. Sürrealizmin her şeyden önce devrim yarattığı şey sanatın temalarıdır ve bunları ifade etmek için her zamanki gibi aynı araçları kullanıyorum. Yeni olan, Freudyenizmden türetilen temalardır." diyen ve 20. yüzyılın anlaşııması en güç yaratıcılarından biri olan Salvador Dali'nin tek bir açıdan incelenmesi ya da çözümlenmesi mümkün değildir (Shanes, 2011, s.14).

20.Yüzyılın büyük sanatçılarından ancak birkaçı kendi yapıtının lideri olmak, yani sanatçıyı hem bir mit hem de bir mit yaratıcısı dolayısıyla da kitle kültürünün bir ikonu olarak inşa etmek konusunda bu kadar başarılı olabilmiştir. Çağdaş sanat üretimiyle pek çok ortak özelliklere sahip bu yanı, onun bir öncü, şöhreti sanatın nüfuz edeceği bir platform haline getirmek konusunda bir çığır açıcı olarak tanımlanmasına yol açar (İstanbul'da Bir Sürrealist Salvador Dali Sergi Kitapçı̆̆ı, 2008).

Sanatıyla olduğu kadar yaşam biçimi, yaşadığı mekanlar ve nesneler, giydiği kıyafetler ve davranış şekli ile dikkatleri üzerine çeken sanatçının mobilyaları ve mobilyayı eserlerinde kullanış şekli bilinçaltı dünyasını açığa çıkaran çalışmalar olmanın yanı sıra günümüzde birçok tasarımcıya ilham kaynağı olmaktadır. Dali mobilyayı gündelik bir eşyadan çok bir sanat eseri olarak görmüş, tasarlamış ve kullanmıştır. Sadece resimlerinde değil; kullanmak üzere ürettiği mobilyalar da metafor içermektedir. Dali mobilyayı eserlerinde sürrealizmi pekiştirmek için kullanmıştır. Mobilya gerek sanatta gerekse günlük yaşamda Dali'nin geçmişi, çocukluğu ve anılarını temsil etmekteydi. Sürrealist sanatçıların birçoğunda mobilya önemli bir metafor olarak kullanılmasına rağmen; mobilyayı bu denli etkili olarak kullanan, mobilya tasarımı yapan ve diğer tasarımcılara ilham kaynağı olan tek bir isim vardır: "Modern sanatın kurtarıcısı Salvador." 


\section{Kaynaklar}

Anderson, Robert. Artists in Their Time Salvador Dali. Franklin Watts, Londra,2002. Breton, Andre. The Automatic Message. London,1997.

Caws, Mary Ann. Salvador Dali. Reaktion Books, Londra,2008.

Chilvers, lan. The Oxford Dictionary of Art and Artists. Oxford University Press, Oxford, 2009.

Dali, Salvador. The Secret Life of Salvador Dali (Second Edition b.). Vision Press, London,1948.

Dali, Salvador. Salvador Dali- Bir Dahinin Güncesi. (S. Aközlü, Çev.) Ara Yayıncılık, İstanbul, 1991.

Demirarslan, Demirarslan. Sakıp Sabancı Müzesi Dali Sergisi Fotoğraf Arşivi, İstanbul, 2008.

Descharnes, Robert., \& Nerret, Gilles. Salvador Dali. Taschen, Berlin, 1989.

Edwards, Garcia, Lorca, Buñuel, Dalí Forbidden Pleasures and Connected Lives. Tauris, London,2009.

Gibson, lan. The Shameful Life of Salvador Dali. W. W. Norton \& Company, 1997.

İstanbul'da Bir Sürrealist Salvador Dali Sergi Kitapçığı. İstanbul: Sakıp Sabancı Müzesi, 2008.

Lubar, Robert. "Barcelona and Modernity: Picasso, Gaudí, Miró, Dalí", Art and AntiArt:Miro, dali and the Catalan Avant-garde, Ed. J. F. William H. Robinson, Yale University Press, 2006, s. 339-349.

McNeese, Tim. The Hispenic Heritage Salvador Dali. Chelsea House Publishes, New York, 2006.

Shanes, Eric. The Life and Masterworks of Salvador Dali. Parkstone Press, New York, 2011.

Üstel Arı, Bahar Başak. "Geçmişten Güncele Venüs”. İdil Dergisi, 8(55), 2019, 321-330.

URL-1. https://www.aquabrava.com/en/cap-de-creus, Erişim Tarihi: 30 Nisan 2021.

URL-2. http://writing.upenn.edu/ taransky/Yellow\%20Manifesto.pdf, Erişim Tarihi: 30 Nisan 2021.

URL-3. Salvador Dali Museum: https://www.salvador-dali.org/en/museums/dali-theatremuseum-in-figueres/visita-virtual/. Erişim Tarihi: 30 Nisan 2021.

URL-4. https://www.dalipaintings.com/galarina.jsp, Erişim Tarihi: 30 Nisan 2021. 
URL-5. https://www.sakipsabancimuzesi.org/tr/object/jeolojik-yanki-pieta, Erişim Tarihi: 30 Nisan 2021.

URL-6. http://archive.thedali.org/mwebcgi/mweb.exe?request=record;id=20;type=101, Erişim Tarihi: 30 Nisan 2021.

URL-7. https://robinrile.com/the-sculpture-of-salvador-dali/. Erişim Tarihi: 30 Nisan 2021.

URL-8. http://www.cnac-gp.fr/education/ressources/ENS-Surrealistart-EN/ENSSurrealistart-EN.htm, Erişim Tarihi: 04 Mayıs 2021.

URL-9. https://www.themodernhouse.com/journal/surreal-surreal-design-objectsproducts-and-furniture/, Erişim Tarihi: 04 Mayıs 2021.

URL-10. https://www.trendhunter.com/trends/surreal-furniture, Erişim Tarihi: 04 Mayıs 2021.

URL-11. http://www.formatd.net/metafor/galeri/yanilsama/21020yanilsama_ugur.htm, Erişim Tarihi: 04 Mayıs 2021.

URL-12. http://www.artnet.com/artists/salvador-dal\%C3\%AD/furniture-studyh8ap9zqwbBXxc0DpRYxk8w2, Erişim Tarihi: 04 Mayıs 2021.

URL-13. https://www.salvador-dali.org/en/artwork/catalogue-raisonnesculpture/resized_imatge.php?obra=84eab9bd42ece411947100155d647f0b\&imatge $=0$ , Erişim Tarihi: 04 Mayıs 2021.

URL-14: https://www.araguler.com.tr/oldcelebritiesphotos.html, Erişim Tarihi: 04 Mayıs 2021.

URL-15. https://wsimag.com/art/62917-in-praise-of-solitude, Erişim Tarihi: 04 Mayıs 2021.

URL-16. https://www.thesocialitefamily.com/en/shop/decorative/picture-of-salvadordali/, Erişim Tarihi: 04 Mayıs 2021.

URL-17. http://mikestravelguide.com/things-to-do-in-cadaques-visit-the-portlligathouse-museum-salvador-dali-house/, Erişim Tarihi: 04 Mayıs 2021.

URL-18. https://jenonajetplane.com/dali-house-cadaques-spain/, Erişim Tarihi: 05 Mayıs 2021.

URL-19. https://www.thevintagenews.com/2018/01/10/salvador-dalis-house, Erişim Tarihi: 05 Mayıs 2021.

URL-20. https://www.dezeen.com/2016/08/11/salvador-dali-most-exciting-cleverperson-oscar-tusquets-blanca-interview-bd-barcelona/, Erişim Tarihi: 05 Mayıs 2021.

URL-21.https://www.dezeen.com/2016/08/11/salvador-dali-most-exciting-cleverperson-oscar-tusquets-blanca-interview-bd-barcelona/, Erişim Tarihi: 05 Mayıs 2021. 
URL-22. https://bdbarcelona.com/es/producto/348, Erişim Tarihi: 05 Mayıs 2021.

URL-23. https://www.sakipsabancimuzesi.org/tr/donem/salvador-dalinin-gizli-yasamiicin-illustrasyonlar-1939-1941, Erişim Tarihi: 05 Mayıs 2021.

URL-24. http://www.artnet.com/artists/salvador-dal\%C3\%AD/mae-west-lips-sofaI_S9hlf9HelM-n5luUf3fw2, Erişim Tarihi: 05 Mayıs 2021.

URL-25. https://www.minniemuse.com/articles/musings/mae-west-room, Erişim Tarihi: 05 Mayıs 2021.

URL-26. http://www.artnet.com/artists/salvador-dal\%C3\%AD/chairs-pairSxw8zv1FFa68V_yRbWdj4w2, Erişim Tarihi: 05 Mayıs 2021.

URL-27. http://blog.milliyet.com.tr/milos-lu-venus/Blog/?BlogNo=603460, Erişim Tarihi: 05 Mayıs 2021.

URL-28. https://spanishculturerediscovered-kbratton.weebly.com/cornerstonepiece.html, Erişim Tarihi: 07 Mayıs 2021.

URL-29. https://www.invaluable.com/auction-lot/salvador-dali-1904-1989-venus-auxtiroirs-47FD54930E, Erişim Tarihi: 07 Mayıs 2021.

URL-30. https://www.apollo-magazine.com/edward-james-surrealism-patron-salvadordali/, Erişim Tarihi: 07 Mayıs 2021.

URL-31. https://www.ragandboneworkshop.co.uk/arm-chair/, Erişim Tarihi: 07 Mayıs 2021.

URL-32. http://www.ems-o.net/zxzhtm/chairs/artn/dali.html, Erişim Tarihi: 07 Mayıs 2021.

URL-33. http://www.ems-o.net/zxzhtm/chairs/artn/dali.html, Erişim Tarihi: 07 Mayıs 2021.

URL-34. https://www.apollo-magazine.com/edward-james-surrealism-patron-salvadordali/, Erişim Tarihi: 07 Mayıs 2021.

URL-35.

http://www.londonfoodfilmfiesta.co.uk/Artmai 1/images 2/dali\%20surrealist\%20dinner.j pg, Erişim Tarihi: 07 Mayıs 2021.

URL-36. https://scalar.usc.edu/works/the-space-between-literature-and-culture-19141945/vol14_2018_king, Erişim Tarihi: 07 Mayıs 2021.

URL-37.

https://bdbarcelona.com/system/pro_downloads/download_es/product/250/ficha_t\%C3 \%A9cnica_Personaje_Invisible_ES.pdf?1470128924, Erişim Tarihi: 07 Mayıs 2021. 